\title{
BEDROCK GEOLOGIC MAP OF THE CAVENDISH QUADRANGLE, WINDSOR COUNTY, VERMONT
}

\author{
By Nicholas M. Ratcliffe
}

\section{INTRODUCTION}

The bedrock of the Cavendish quadrangle consists of highly metamorphosed garnet- and staurolite-kyanite-grade gneiss and schist that most recently have been strongly affected by the Acadian orogeny. The area encompasses the northern termination of an Acadian structure, the Chester dome (fig. 1), which contains core rocks of Middle Proterozoic age that are comparable to core rocks of the Mount Holly Complex exposed in the Green Mountain massif to the west. Schists, marble, and granofels previously assigned either to the Cavendish Formation (Doll and others, 1961) or to the Hoosac Formation (Thompson and others, 1993) were thought to be the inner cover that was folded into the core of the dome. The age and structural position of these rocks are problematic. They could be cover rocks younger than the Mount Holly Complex, but from my mapping in the region, I believe they are part of the Mount Holly Complex. The principal outcrops of these rocks are at Hawks Mountain on the southern border of the map and near Star Hill in the west-central part of the map.

Overlying the core rocks of the dome is a $1-\mathrm{km}$-thick section of highly folded and faulted cover rocks. The correlation of these rocks with those making up the eastern cover of the Green Mountain massif is uncertain. However, the rocks immediately above the core are Cambrian, Ordovician, and possibly Silurian, although actual age and correlation are uncertain.

The Waits River Formation of Silurian and Early Devonian age (Doll and others, 1961; Hatch, 1991) unconformably overlies these early Paleozoic rocks. Although structures in all the cover rocks are parallel and conform with the northward plunge of the dome, complex structures within the dome and its mantle indicate all have been affected by the Grenvillian and Taconian orogenies. Intricate models of Acadian deformation in the area were developed by Thompson (1950) and Rosenfeld (1968) and illustrated by Doll and others (1961). In the models, the basement and cover rocks of the dome formed recumbent folds or nappes having an amplitude of about $15 \mathrm{~km}$ (fig. 1). Subsequent doming left the keel of the inverted basement perched in a synform, the Butternut Hill fold, and inverted cover rocks in a major antiform exposed at Star Hill, the Star Hill fold.

A major goal of this investigation was to map in detail the previously unmapped Mount Holly Complex of the dome and to determine the compatibility of the structure in the basement rocks to the proposed nappes of basement and cover.

\section{PREVIOUS WORK}

In mapping the Chester dome, Thompson (1950) also mapped the Ludlow 15-minute quadrangle, which includes the Cavendish 7.5-minute quadrangle, and adjacent areas at the scale of 1:62,500 (fig. 2); this work was updated by Thompson and others (1993).
Chang and others (1965) mapped the Woodstock 15-minute quadrangle to the north that complimented the earlier work of Thompson and also developed the regional stratigraphy and structure illustrated in Doll and others (1961). Nisbet (1976) mapped the Keyes Mountain area at the scale of 1:2,400 and studied the general structure of the Chester dome. Downie (1982) mapped the Star Hill area and studied the metamorphic petrology. Ratcliffe (1992) mapped the Mount Holly 7.5-minute quadrangle and the western part of the Ludlow 7.5-minute quadrangle. Ratcliffe and Walsh completed mapping of the Ludlow quadrangle and produced a geologic map of the Mount Holly and Ludlow quadrangles (N.M. Ratcliffe and G.J. Walsh, unpub. data, 1993).

The geology of the Chester and Athens domes is summarized by Thompson and others (1993) (fig. 1). The northern end of the Chester dome was illustrated in cross section $E-E^{\prime}$ of Doll and others (1961). Figure 3, a cross section across the Chester dome in figure 1, shows that Middle Proterozoic core rocks and lower and middle Paleozoic cover rocks are folded in a large recumbent, westverging nappe, the Butternut Hill fold, and an ancillary recumbent syncline, the Star Hill fold. According to models of Thompson (1950) and of Rosenfeld (1968), later Acadian deformation, accompanied by the buoyant uprising of lighter core rocks, produced upwarping of the dome and adjacent tightly pinched synclines.

Similar cross sections in Thompson (1950) and Thompson, Rosenfeld, and Downie (1986) cite the northern plunge of the Butternut Hill and Star Hill folds. The rotation senses of minor folds were used to support the synformal and antiformal shape of the Butternut Hill and Star Hill folds.

The Star Hill fold of Thompson (1950) extended from near Grafton to Star Hill (Doll and others, 1961). Subsequent versions of the geology of Thompson, Lyttle, and Thompson (1977) and Thompson and others $(1990,1993)$ (see fig. 1) terminate the fold at Cavendish and show isolated areas of cover rock at Star Hill due, in part, to more detailed mapping of the Star Hill area by Downie (1982) shown in figure 4. Rocks within the core of the fold previously mapped as Hoosac Formation were remapped as Mount Holly Complex and were enclosed by two belts of cover rock. The inner belt at Star Hill consists of the Hoosac and Pinney Hollow Formations, whereas the outer belt of schists and gneisses was mapped as Hoosac Formation by Thompson and others (1993).

Nisbet (1976) mapped the Keyes Mountain area (fig. 2) in detail and did reconnaissance studies of the Butternut Hill fold. He concluded that Thompson's use of rotation sense of minor folds in confirming the form of the major folds was not consistent and that many of these minor folds were the result of late interference folds; consequently, they could not be used to determine stratigraphy or structure.

In Downie's interpretation (1982, p. 269), rocks of the Star Hill area occur in an antiformal warp of inverted Hoosac and Pinney 


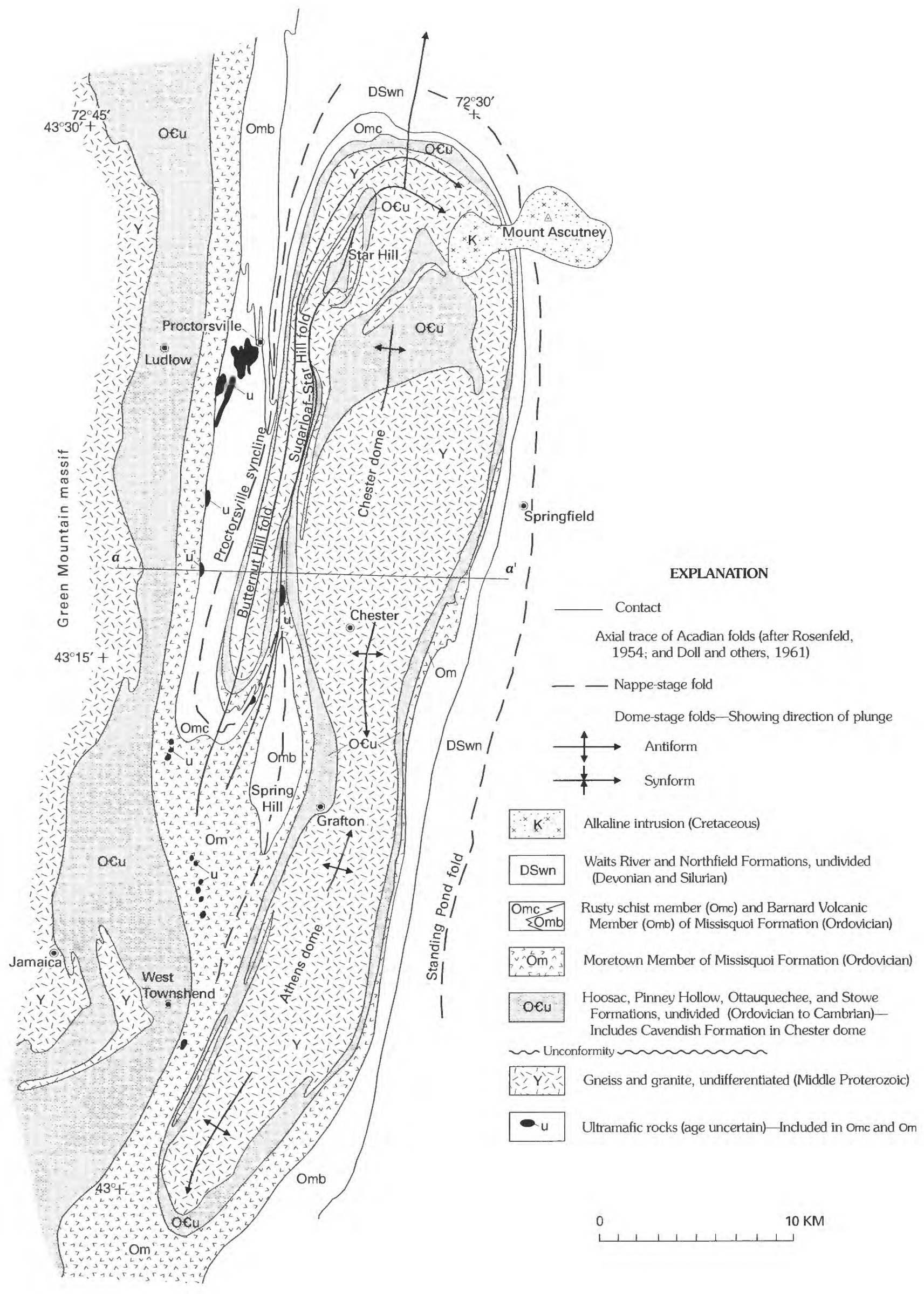


$\leftarrow$ Figure 1.-Generalized geologic map of the Chester and Athens domes showing previous interpretations and axial traces of major Acadian folds according to Doll and others (1961), Thompson (1950), and Thompson and others (1993). Note different interpretation with present geologic map. Cross section $a-a^{\prime}$ is shown in figure 3.

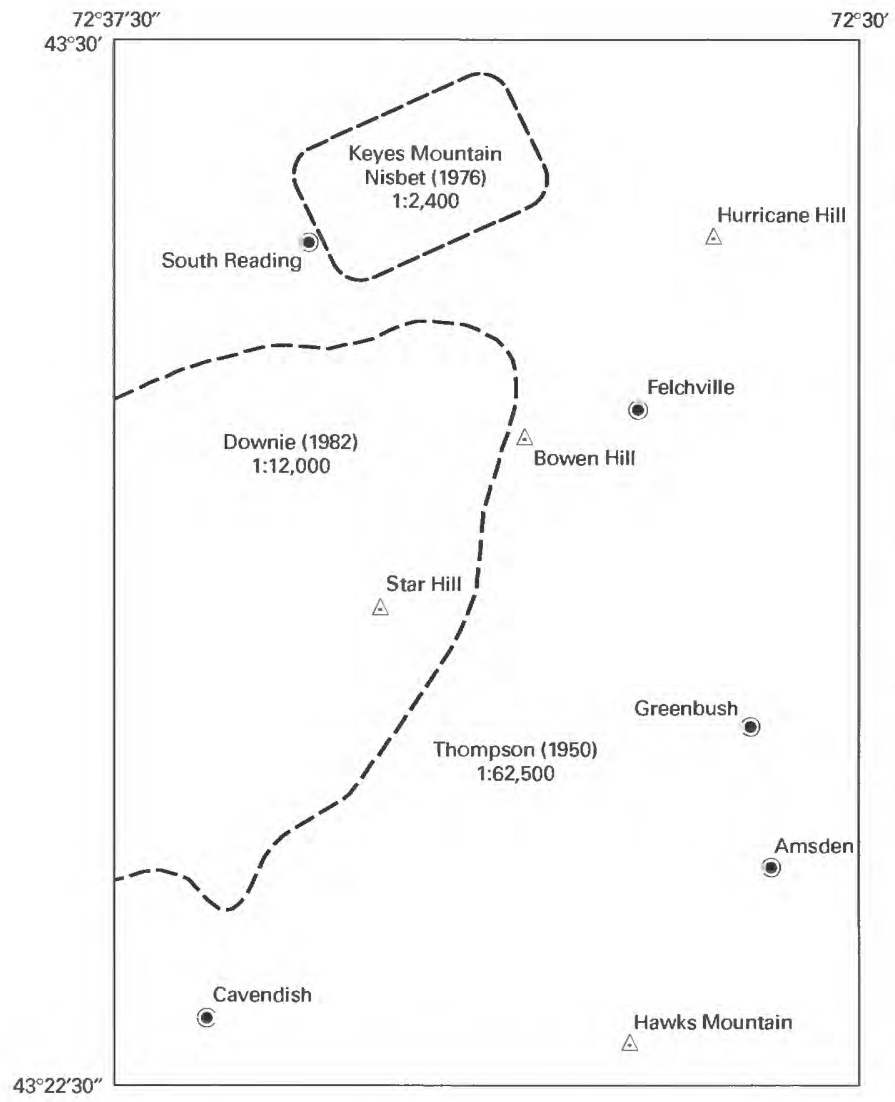

Figure 2.-Index map showing previous geologic mapping in the Cavendish quadrangle. Ratcliffe (1992) mapped the Mount Holly and part of the Ludlow 7.5-minute quadrangles to the west at the scale of $1: 24,000$, and Chang and others (1965) mapped the Woodstock 15-minute quadrangle to the north at the scale of $1: 62,500$.

Hollow rocks that appear through the mantling of Mount Holly rocks (figs. 4 and 5). Three areas of cover rocks are exposed. Near the western edge of the map, an outer mantle of Hoosac Formation and Pinney Hollow Formation parallels the western margin of the dome. The Hoosac and Pinney Hollow Formations also occur as an inner cover in the core of the Star Hill fold following the earlier usage of Thompson (1950) and Doll and others (1961). These rocks are thought to be the emergence of the mantle of the dome exposed in a major antiform. A continuous belt of Mount Holly Complex ( $Y$ on fig. 4) encircles the core of the antiform; this belt was originally mapped as Hoosac Formation by Thompson (1950). Beyond this belt Downie mapped calc-silicate gneiss, granofels, and schist tentatively as Hoosac Formation ( $€ Z h$ ? on fig. 4); this belt corresponds to the outermost belt of the Cavendish Formation at Star Hill shown by Doll and others (1961). Rocks of the Mount Holly Complex again encircle the area.

In Downie's structural interpretation (1982), outer cover rocks (€Zh?) were folded into the basement rocks. A major downwardfacing, overturned isoclinal synform, the Butternut Hill fold, and its complementary Star Hill antiform (fig. 5A) formed during the Acadian. The regional foliation (her $\mathrm{S}_{2}$ ) is parallel to the axial trace of these folds, which formed prior to the doming (fig. $5 B$ ), also considered Acadian. Figure $5 B$ represents what is shown in the map in figure 4. Downie's model (fig. 5) for the structural evolution of the Star Hill and Butternut Hill folds and their subsequent doming in the Acadian is illustrated in the diagrammatic section along section $a-a^{\prime}$ of figure 4 . She envisions an early, possibly Taconian infolding of the outer cover ( $€ \mathrm{Zh}$ ?) into the basement. This was followed by development of isoclinal recumbent Acadian nappes (fig. $5 A$ ) to produce the Butternut Hill and Star Hill folds. The present form following doming is shown in figure $5 B$. The separation of the inner cover units ( $\mathrm{CZh}$ ? and $€ \mathrm{ph}$ ?) from those of the outer mantle of the dome (O€u in fig. 5) was produced by megaboudinage during the doming so that the axial trace of the Star Hill fold is no longer continuous on the ground (Downie, 1982, p. 264, 269).

Downie expanded on the ideas of Thompson (1950) and Rosenfeld (1968). In order to confirm the nappe theory, several questions need to be answered.

(1) Does the north plunge of the Star Hill fold mean the basement and cover are inverted?

(2) Does deformation of the basement rocks involved in the proposed nappes match the deformation in the cover rocks?

(3) Do major and minor folds and foliation related to Acadian folding cause the symmetry of both the cover rocks and the Mount Holly Complex?

(4) Do the cover rocks at Hawks Mountain and Star Hill (Cavendish Formation of Doll and others, 1961) correlate structurally with lower rocks in the mantle of the dome?

\section{STRATIGRAPHY}

The rocks of the Cavendish quadrangle range in age from Middle Proterozoic to Cretaceous. The core rocks of the Chester dome are mapped here as Middle Proterozoic, but previous workers have mapped some rocks, in particular the aluminous schists and feldspathic schists of the Cavendish Formation on Hawks Mountain and Star Hill, as younger cover rocks (fig. 6). The mantle of the dome consists of two packages of rocks. The lower package contains feldspathic and aluminous schists, granofels, and amphibolite mapped here as the Moretown Formation of probable Ordovician age. The upper package of rocks forming an outer belt contains the Barnard Gneiss of Ordovician and Silurian age and the unconformably overlying Waits River Formation of probable Silurian and (or) Early Devonian age.

\section{Core rocks of the Chester dome- the Mount Holly Complex}

As mapped here, the Mount Holly Complex consists largely of a sequence of interlayered paragneiss units and intrusive rocks. These are repeated by folding or, locally, lenses of similar material are repeated by interdigitation. Schist, marble, calc-silicate gneiss, quartzite, amphibolite, and other well-layered gneisses support the sedimentary and volcanic origin.

Two areas of paragneiss and schist, previously mapped as Cavendish Formation, are very similar to schists and gneisses that 


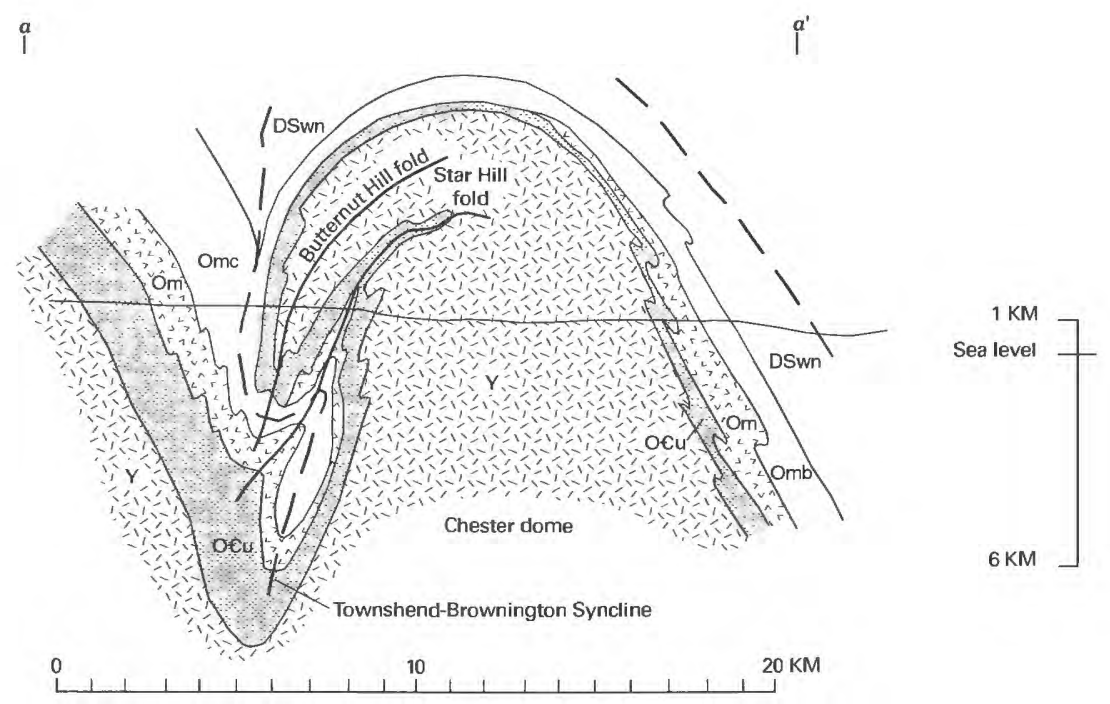

Figure 3.-Cross section of the Chester dome according to section $E-E^{\prime}$ of Doll and others (1961) showing position of the Butternut Hill and Star Hill folds. See figure 1 for location and explanation of units. Omc and Omb are combined as one undifferentiated unit.

are interbedded throughout the Mount Holly Complex. I consider the Cavendish Formation as a stratigraphic unit within the Mount Holly. Other paragneiss units of the Mount Holly Complex are intruded by granodiorite gneiss to trondhjemite (Yfgt), aplite (Yfap), and less abundant microcline-rich granitic gneiss (Ygg) and pegmatite $(Y p)$. The granodiorite to trondhjemite gneiss and aplite (Yfgt and Yfap) are referred to here as the Felchville Gneiss for exposures at and near Felchville.

The dominant unit of the Mount Holly Complex is a well-layered sequence of biotite-quartz plagioclase gneiss $(\mathrm{Ybg})$ that incorporates lenses and thicker layers of rusty-weathering, sulfidic and nonsulfidic gneisses and schists. These rusty schists and gneisses ( $\mathrm{Yrg})$ consist principally of thick layers of dark-gray biotite gneiss and rusty-weathering gneiss and amphibolite (Ya). Beds of vitreous gray quartzite and garnet-biotite quartzite (Yrq), calc-silicate gneiss ( $\mathrm{Ycs}$ ), and marble ( $\mathrm{Ym})$ are common. A distinctive, but narrow belt of garnet-rich, dark-gray biotite gneiss and schist (Yrgt) commonly associated with thin unmapped beds of sulfidic hornblende-diopside calcsilicate gneiss occurs along the western side of the dome. The rusty-weathering units ( $\mathrm{Yrg}, \mathrm{Yrq}$, and $\mathrm{Yrgt}$ ) are extensively intruded by pegmatite $(\mathrm{Yp})$. Near thick lenses of pegmatite, a much thinner variant of unit Yrg is a yellow-green, very muscovitic, and chloritized garnet schist, which is mapped as Yrs; it closely resembles aluminous schist in the Cavendish Formation.

The age of the Mount Holly Complex in the Cavendish area was documented solely by lead-alpha age on zircon of $900 \mathrm{Ma}$ (Faul and others, 1963) and an age determination of approximately 955 $\mathrm{Ma}$ on the Bull Hill Gneiss, which intrudes the Mount Holly Complex (Karabinos and Aleinikoff, 1990; Ratcliffe, 1991). The Bull Hill Gneiss intrudes the Mount Holly Complex in the Athens dome in the Townshend quadrangle (Ratcliffe, 1991). New infor- mation cited in this report indicates that the Felchville (Yfgt) and aplitic gneiss (Yfap) may be as old as 1,424 Ma.

\section{Cavendish Formation}

The name Cavendish Formation is used here for a large area of biotite-quartz-plagioclase schist and lustrous garnet-kyanite-staurolite-biotite-muscovite-quartz schist that locally was called the Gassetts Schist (Richardson, 1929) from exposures at the quarry and mine at Gassetts in the adjacent Chester quadrangle near Hawks Mountain. Richardson (1929) separated the Gassetts and Cavendish Schists; the Gassetts Schist was thought to overlie the Cavendish at both Gassetts and near Springfield, and the Gassetts Schist was assigned to the younger Missisquoi Group of Richardson (1929). Thompson (1950) included the Cavendish in his Hawks Mountain complex that in descending order included (1) the Cavendish Schist, (2) the Whitesville marble (Thompson, 1950) consisting of thin dolomite, various calc-silicate rocks, and minor quartzite, and (3) the Reading Gneiss (Richardson, 1929) (fig. 6). Thompson combined the aluminous Gassetts Schist and Richardson's Cavendish Schist. The Reading Gneiss mapped by Thompson (1950) included the remaining gneissic rocks of the Middle Proterozoic core of the dome. Thompson regarded all of his Hawks Mountain complex to be part of the older basement. Similar rocks in the Star Hill area, including the Star Hill Formation of Thompson (1950), Bull Hill Gneiss and Grahamville Formation of Thompson (1950) were regarded as younger than the rocks of his Hawks Mountain complex.

Doll and others (1961) separated the Cavendish from the underlying Mount Holly Complex (formerly the Reading Gneiss of Thompson, 1950); the Cavendish and underlying marble (formerly the Whitesville marble of Thompson, 1950) were assigned to the 


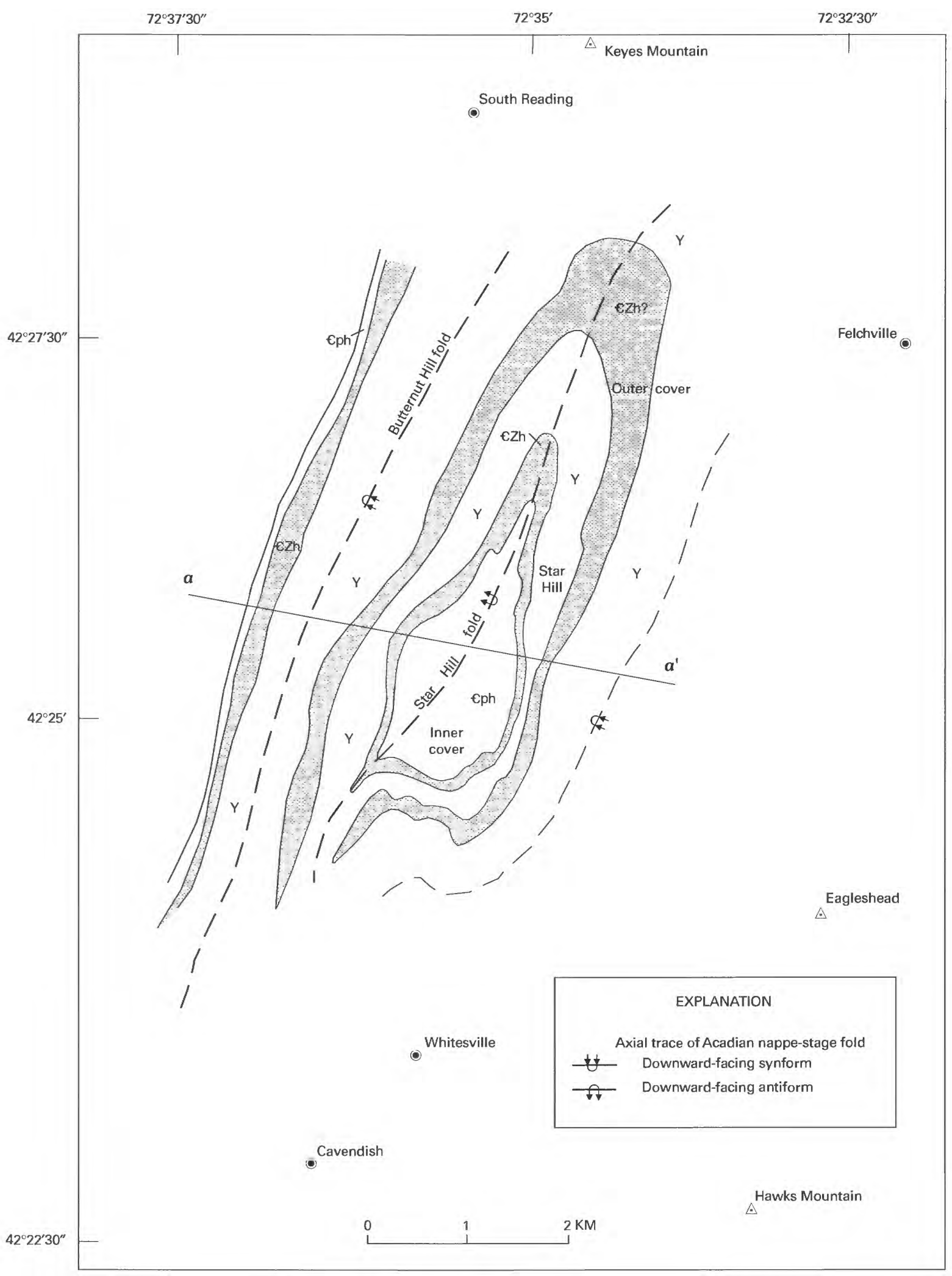

Figure 4.-Generalized geologic map of the Star Hill area, Cavendish quadrangle, as portrayed by Downie (1982, figs. 3-6) showing axial traces of Acadian nappe-stage folds. Map units from oldest to youngest are $Y$, Mount Holly Complex; $€ Z \mathrm{~h}$ ?, Hoosac(?) Formation of the outer cover; $€ \mathrm{Zh}$, Hoosac Formation; €ph, Pinney Hollow Formation. Structural evolution along general cross section $a-a^{\prime}$ is shown diagrammatically in figure 5 . 
$A$

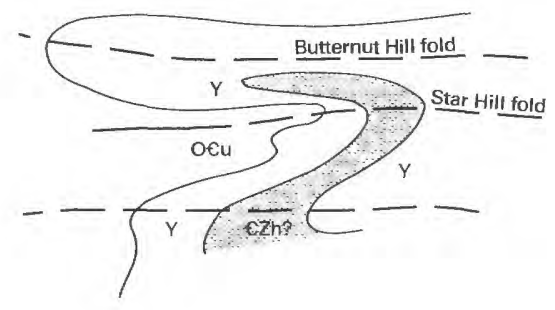

B

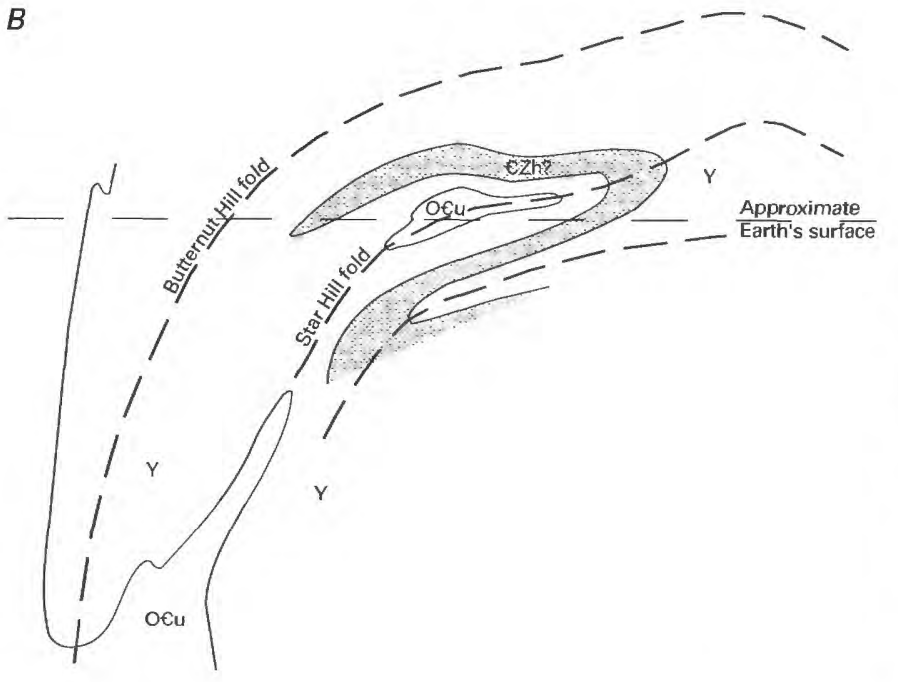

Figure 5.-Diagrammatic structural evolution of the Star Hill area according to Downie (1982, fig. 7-1). See figure 4 for location and explanation of units. A, Acadian nappe stage showing development of the recumbent Butternut Hill and Star Hill folds. $B$, after doming (see text discussion). O $\mathrm{\epsilon u}$ equivalent to $€ \mathrm{Zh}$ and $€ \mathrm{ph}$ of figure $4 ; € Z \mathrm{~h}$ ? is belt defined by Downie, of uncertain correlation (see fig. 6).

cover sequence, which rested unconformably on the Mount Holly (fig. 6). Thompson assigned rocks of the Star Hill area (Doll and others, 1961) to the Cavendish. Doll and others (1961) included the following rocks in descending order in the Chester dome: (1) Hoosac Formation, (2) Cavendish Formation, (3) marble and calcsilicate rock, (4) microcline-augen gneiss (the Bull Hill Gneiss of Richardson, 1929), and (5) Mount Holly Complex.

More recently (Thompson, Lyttle, and Thompson, 1977; Thompson and others, 1993), the name Cavendish was abandoned in favor of the Hoosac Formation, which included schists formerly regarded as the Cavendish Formation, as well as the Star Hill Formation and the marble unit (the Whitesville marble of Thompson, 1950) (fig. 6). They correlated the marble and associated thin quartzite with dolomite and quartzite of the Tyson Formation of Cambrian age on the eastern flank of the Green Mountains in the Plymouth, Killington Peak, and Ludlow quadrangles.

The present report addresses the uncertainty in age and map relations of the basement and cover rocks in the Chester dome. Basic lithologic contacts have not changed significantly from the map of Thompson (1950), but the name designations have changed considerably. I began field studies of the type Cavendish and its relation to the adjacent rocks in 1992 in order to understand the relations between the Reading Gneiss (Thompson, 1950), the Mount Holly Complex of Doll and others (1961) and of Thompson and others (1993), and the cover sequences.

My interpretation is markedly different from earlier ones. I include both the Star Hill Formation and Cavendish Schist of Thompson (1950) as integral parts of the Mount Holly Complex, instead of being younger rocks. In the maps and sections from Doll and others (1961), Thompson and others (1993), and Downie (1982) (figs. 1, 3-5), rocks assigned to the cover sequence at Star Hill form complex refolded antiforms or nappes emerging from beneath the surrounding Mount Holly Complex; this could require inverted segments of basement and cover. Thompson's (1950) observation that the rocks of the Star Hill fold plunge northward under the Mount Holly at the northern closure of the fold is a key element in the nappe interpretation.

I have retained the name Cavendish Formation in the sense used by Thompson (1950), but I have extended its use to include some of the rocks on Star Hill, including both the inner and outer cover of Downie (1982) that had been assigned to the Hoosac and Pinney Hollow Formations. The difference is slight between aluminous schists, with or without abundant garnet and calc-silicate gneiss or marble, found in the Mount Holly Complex (mapped here as units Yrs, Yrg, Ycs, and $Y \mathrm{~m}$ ) and similar units of the Cavendish $(Y \mathrm{cg}, Y \mathrm{ccs}, \mathrm{Ycm}$, and $\mathrm{Ycfs})$. Only the marble and calc-silicate units that are in contact with Cavendish schists are mapped as Cavendish here (units $\mathrm{Ycm}$ and $\mathrm{Yccs}$ ). This distinction is somewhat arbitrary, but is analogous with the original usage of Thompson (1950), who associated the Whitesville marble with the Cavendish. The type section is at Cavendish Gorge.

\section{Contact relations}

Cavendish Gorge area.-Extensive exposures of contacts between feldspathic schist and marble in the Cavendish ( $\mathrm{Ycfs}$ and $\mathrm{Ycm}$ ) occur along the Black River northward from Cavendish Gorge to $60 \mathrm{~m}$ north of the electric powerplant. Here gray-to-white finegrained dolomite-calcite marble ( \pm diopside, actinolite, and talc), vitreous white quartzite, and dark-gray albitic granofels are interbedded in a 3-m-thick band. The contacts are gradational, demonstrating clearly the interbedded nature of the feldspathic schist, granofels, marble, and quartzite. The calcite-dolomite-quartz mineral assemblage is dominant in conjunction with knotty-appearing calcsilicate rocks containing masses of tremolite, chlorite, talc, and, less commonly, diopside. Immediately above the dolomite and quartzite is a white aplitic gneiss unit (Yfap) of the Mount Holly, a local variant of the Felchville. In the gorge area the white aplitic gneiss (Yfap), which is too thin to map, is in contact with feldspathic schist, white dolomite, and more aluminous schist of the Cavendish (units $Y \mathrm{cfs}, \mathrm{Ycm}$, and $\mathrm{Ycg}$ ). Along the western bank of the gorge, the aplite truncates and encloses several marble and calc-silicate gneiss units ( $\mathrm{Ycm}$ and $\mathrm{Yccs}$ ); the best exposures are near the vertical joint face of the western wall of the gorge from the dam and extending downstream about $50 \mathrm{~m}$. On the eastern bank of the gorge, the same white aplitic gneiss is in contact with aluminous and feldspathic variants of the Cavendish. Farther downstream, a coarser grained variant of the Felchville (Yfgt) is in contact with the Cavendish Formation (Ycfs). None of the numerous exposed contacts are sheared and indeed the contacts appear to be intrusive.

Along both banks downstream of the powerplant, a coarse diopside-hornblende scarn developed where the aplitic gneiss of the Felchville (Yfap) is in contact with white dolostone. West of the stream in the woods about $200 \mathrm{~m}$ south of the powerplant, calc-sil- 


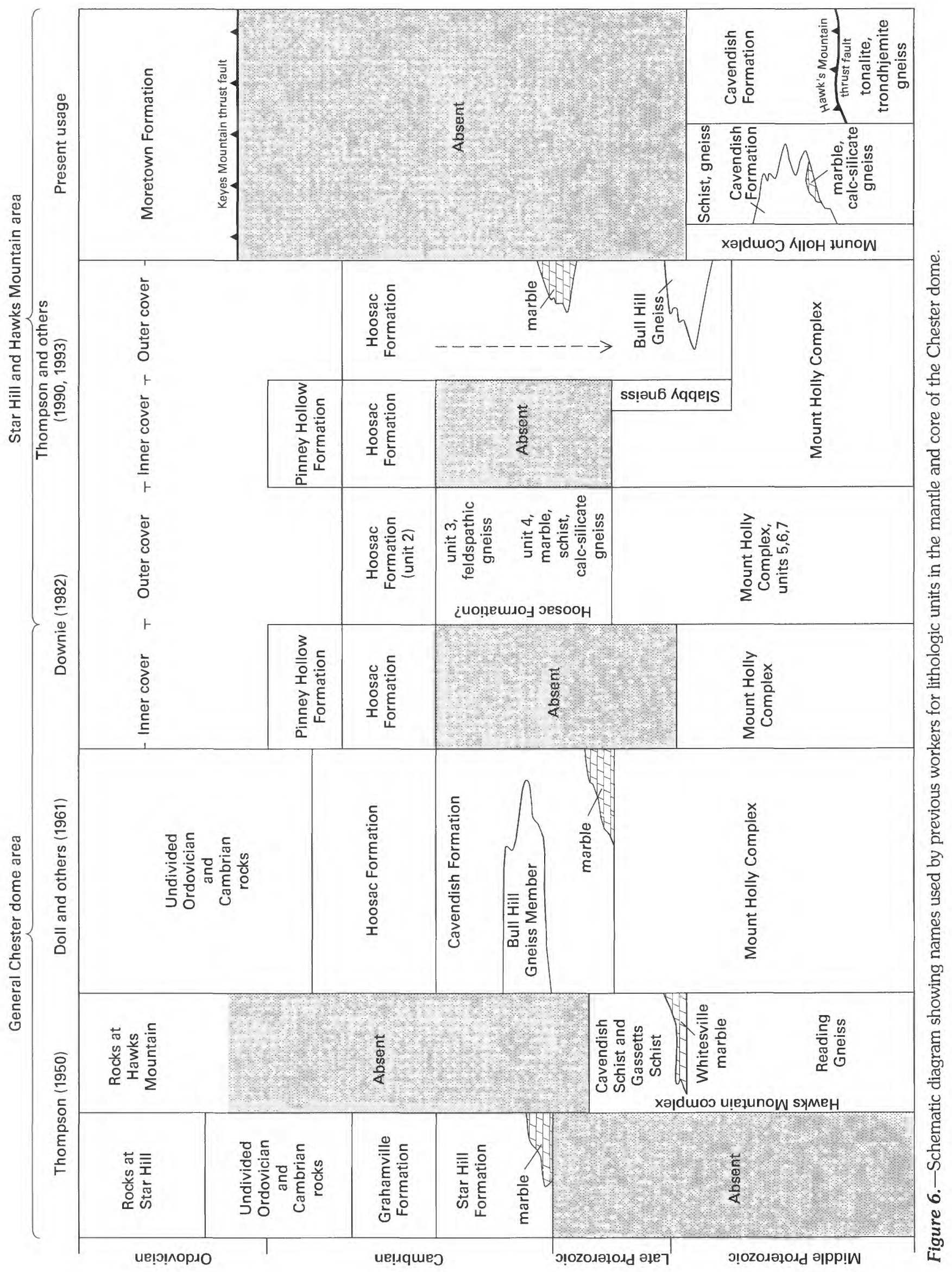


icate gneiss merges into the aplite gneiss of the Felchville. Elsewhere, this aplite contains distinct xenoliths of biotite gneiss (Ybg) of the Mount Holly Complex. The aplitic rock (Yfap) is clearly an intrusive rock.

Similar relations can be seen near Whitesville, in the low hills northwest of the Black River, and in the Black River opposite the intersection of State Route 131 and Windy Hill Road. All along the contact of the Cavendish from the southern border of the map northward to Hurricane Hill in the northeastern part of the map, are tiny interlayered conformable lenses of caic-silicate gneiss, marble, and aluminous schist within the biotite-quartz-plagioclase gneiss (Ybg) and the aplitic gneiss (Yfap) of the Mount Holly Complex that closely resemble units of the Cavendish. The aplitic gneiss (Yfap) and granodioritic gneiss (Yfgt) units of the Felchville intrude all other units of the Mount Holly Complex, as well as the Cavendish Formation. Because Cavendish units are found within the Mount Holly and vice versa and Felchville units are found in both, it seems logical that the entire mass of Cavendish should be considered part of the Mount Holly Complex.

A series of parallel calc-silicate gneisses, marbles, and aluminous schist layers occurs within the Mount Holly Complex south of Cavendish Gorge and west of the Cavendish contact. These units include lenses of aplitic to granodionitic gneiss (Yfgt) and extend southward into the Duttonsville Gulf area in the Chester quadrangle. However, a contact between schists of the Cavendish and biotitic gneisses (Ybg) of the Mount Holly Complex with no intervening calc-silicate or marble units has been exposed recently in excavations on the east side of Duttonsville Gulf $1.5 \mathrm{~km}$ south of the quadrangle.

Previously several layers of calc-silicate gneiss and calcitedolomite marble exposed in Cavendish Gorge were mapped as a single unit at the base of the Cavendish (Doll and others, 1961); my work indicates this clearly is not the case. The calc-silicate gneiss exposures at Gassetts studied by Thompson (1975), the marble sampled by Sheppard and Schwarcz (1970) in Duttonsville Gulf, and the marble and calc-silicate gneiss exposures in Cavendish Gorge are probably not the same layer, but, instead, are different layers within the Mount Holly Complex.

In mapping the type section of the Cavendish southward, the calc-silicate, marble, and schist layers continue within the Mount Holly gneisses, parallel the Cavendish contact, and also include the aplitic gneisses that intrude the Cavendish rocks.

Hawks Mountain area.-The base of the Cavendish Formation, however, has quite a different contact relation with the underlying gneisses. An intensively developed zone of mylonite marks the contact from Gassetts in the Chester quadrangle northeastward along the crest of Hawks Mountain. This zone consists of darkgray biotite porphyroclastic gneiss and mylonite schist that is 50 to as much as $200 \mathrm{~m}$ thick at the eastern end of Hawks Mountain.

This transition appears as a coarse-grained, biotite-spotted trondhjemite and tonalite gneiss $(\mathrm{Yt})$ that has an intense penetrative mylonitic foliation dipping approximately $10^{\circ}$ to $15^{\circ}$ north-northwest. Mylonite zones spaced meters apart transect the coarse gneiss, weave around elongated blocks, knots, and sheared-off fold noses, and produce pronounced zones of disarticulation in the plane of mylonitization.

The transition upward into the Cavendish Formation is gradual and well exposed along the south-facing cliffs of Hawks Mountain. The gneiss becomes increasingly sheared upward until it appears as a darker, finer grained biotite mylonite schist. This mylonite schist contains two distinctive rocks. The first is a phacoidally sheared plagioclase-"augen" mylonite (Yta) in which porphyroclasts of plagioclase 1 to $2 \mathrm{~cm}$ long compose 70 percent of the rock. The other is a porphyroclastic, dark-gray, biotite schist (Ytm), which contains smaller, mylonitically milled composite grains of plagioclase 1 to $0.5 \mathrm{~cm}$ long, biotite, and quartz. The plagioclase "grains" have distinctive growth tails and asymmetric shapes typical of mylonitic porphyroclasts that have been modified by recrystallization and dynamic regrowth. The contact between these two types is gradational and is shown by patterns on the geologic map and sections.

Within about $20 \mathrm{~m}$ of the contact with the Cavendish, the transitional rocks are fine-grained, uniformly foliated schists and blastomylonite, in which are less deformed elliptical to tabular pods of gneiss 5 to $10 \mathrm{~cm}$ thick. The contact with the aluminous Gassetts Schist Member $(\mathrm{Ycg})$ can be located to within $2 \mathrm{~m}$ in the western part of the Chester quadrangle. Eastward from the crest of Hawks Mountain (peak 2,092 ft, Chester quadrangle), the contact becomes more difficult to recognize because the biotite feldspathic schist of the Cavendish (Ycfs) closely resembles and is transitional with the mylonite derived from the tonalite gneiss of the Mount Holly Complex.

At the eastern end of Hawks Mountain, the trend of the mylonitic foliation turns sharply to the south and undergoes intense plication in N. $25^{\circ}-30^{\circ}$ E.-trending later folds that have steeply southeast-dipping axial surfaces. Mylonitic, porphyroclastic gneiss, similar to that along the lower and intermediate slopes of Hawks Mountain, occurs between the 600 to $700 \mathrm{ft}$ altitude of Quarry Road, southwest of Perkinsville in the northeastern corner of the Chester quadrangle.

The lower contact of the Cavendish Formation on Hawks Mountain is interpreted as a thrust fault, here named the Hawks Mountain thrust. The Hawks Mountain thrust truncates the contact between the feldspathic schist member (Ycfs) and the Gassetts Schist Member $(\mathrm{Ycg})$ of the Cavendish in the hanging wall (cross sections $C-C^{\prime}$ and $E-E$ ). South of the quadrangle, the Cavendish disappears and gneissic rocks of the Mount Holly Complex form both the footwall and hanging wall.

In summary, the Cavendish Formation in the Hawks Mountain area of the Cavendish and Chester quadrangles forms an intrusive contact with granodiorite gneiss of the Mount Holly Complex (units Yfgt and Yfap) and is interlayered with the biotite-quartz-plagioclase gneiss of the Mount Holly Complex (Ybg). The lower contact of the Cavendish Formation with tonalite-trondhjemite gneiss of the Mount Holly Complex $(\mathrm{Yt})$ is interpreted here as a fault, but it may have been originally an intrusive contact.

Star Hill area.-The outer belt of aluminous schist (Ycg) and minor calc-silicate rocks of the Cavendish Formation at Star Hill is mapped in the same position as the Star Hill Formation of Thompson (1950) and the Cavendish Formation of Doll and others (1961). Most of this belt is muscovite-rich, garnetiferous staurolitequartz \pm kyanite schist of the Gassetts Schist Member. East of Hardy Hill Road it extends northward, where it parallels abundant granitic gneiss $(\mathrm{Ygg})$ and pegmatite $(\mathrm{Yp})$ to the east and widens to about 0.5 $\mathrm{km}$ farther north. Good outcrops occur on the north-facing slopes south of North Branch of the Black River. Along the western outcrop margin are two areas of white, tremolite-rich marble and calcsilicate rock $(\mathrm{Ycm})$ in contact with a narrow selvage of feldspathic Cavendish (Ycfs). No outcrops occur below 1,300 ft to the North Branch of the Black River, but north of the river are outcrops of rusty aluminous garnet schist and more feldspathic schist. The schist terminates in a complex fold with the surrounding biotitequartz-plagioclase gneiss (Ybg) of the Mount Holly.

On Star Hill west of Hardy Hill Road, a narrow band of calcitediopside marble and calc-silicate gneiss (Ycs) $5 \mathrm{~m}$ thick is interbedded with biotite gneiss (Ybg) typical of the Mount Holly Complex. 


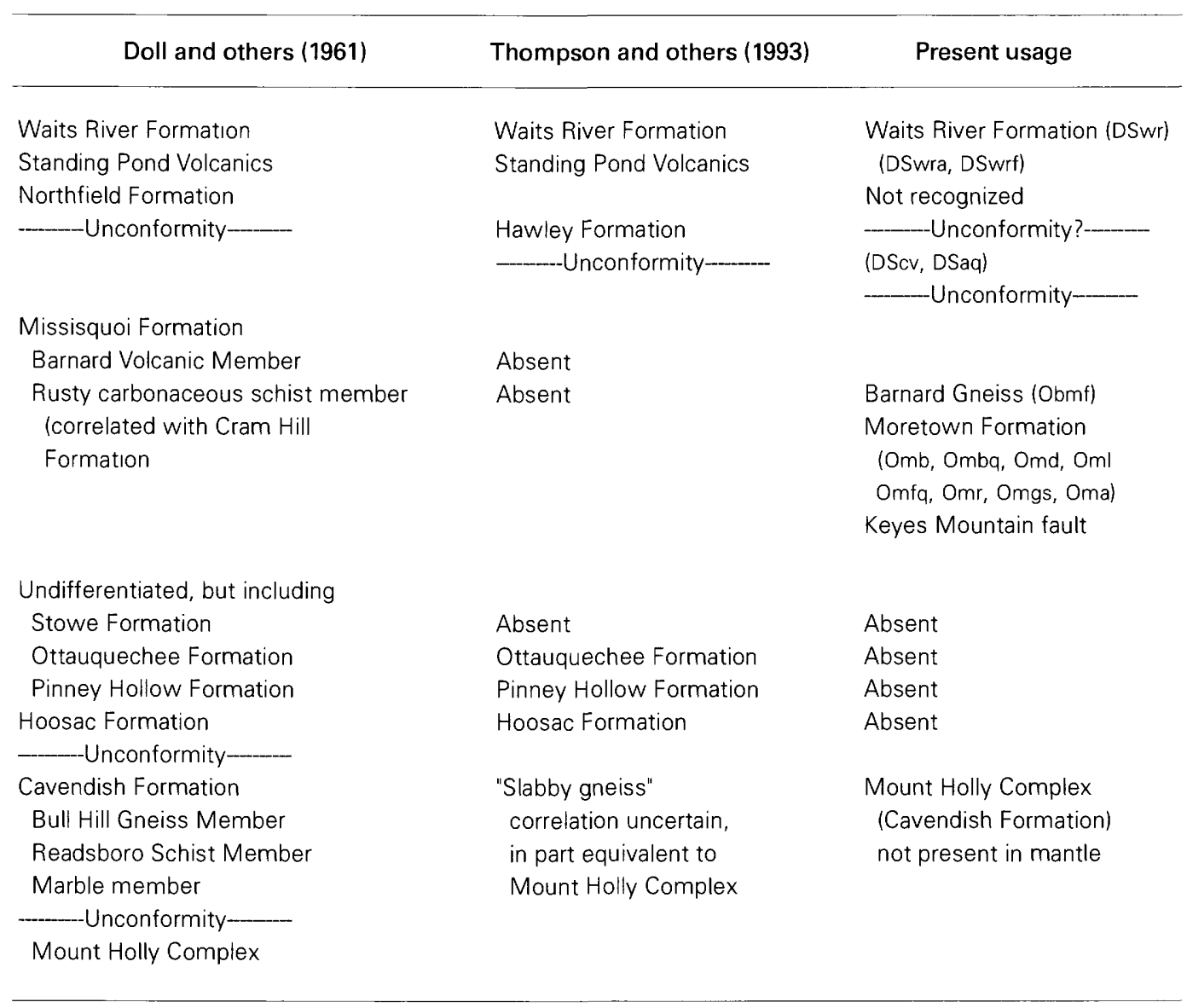

Figure 7.-Correlation of mantle rocks of the Chester dome in the Cavendish quadrangle.

This band of calc-silicate rock extends intermittently about $300 \mathrm{~m}$. To the west of the calc-silicate rocks and a narrow band of biotitehornblende gneiss $(\mathrm{Ybg})$ is another band of rusty aluminous schist mapped as unit Yrs that is not quite as coarse grained as the Gassetts Schist Member mapped east of the road. This very narrow belt can be traced more than $1 \mathrm{~km}$; its northern tip disappears into a mass of coarse pegmatite (Yp). This Yrs schist is overlain by typical biotite microcline-plagioclase-quartz gneiss ( $\mathrm{Ybg}$ ) of the Mount Holly and contains a sill of aplitic gneiss (Yfap). Slightly higher on the southern end of Star Hill is a third layer of rusty muscovite-biotite schist (Yrs) similar to but not identical with the lower one; it is less than $100 \mathrm{~m}$ long and terminates into biotite-quartzplagioclase gneiss (Ybg).

The eastern contact of the lower Yrs unit, possibly the calc-silicate (Ycs) near the base of the hill, and the Gassetts Schist Member (Ycg) of the Cavendish Formation are truncated against the belt of aplitic gneiss, granite pegmatite, and granodioritic gneiss (units Yfap, Yp, and Yfgt). The overall relation mapped at Star Hill duplicates those in Cavendish Gorge and Duttonsville Gulf. Thus, the Cavendish Formation here must also be part of the Mount Holly.

The irregular southern mass of aluminous rocks mapped here as Cavendish was mapped as the Pinney Hollow Formation by Thompson (1950) and Downie (1982). Limited exposures do not reveal its connection with the rest of the Cavendish rocks in the Star Hill area. However, these aluminous garnetiferous schists are mineralogically identical to the lower two aluminous schists (Yrs and
Ycg) east of Star Hill (Downie, 1982). The contact with adjacent gneisses of the Mount Holly are well defined on the western slopes of Star Hill. There and south along the powerline, the schist contains thin lenses of calc-silicate gneiss and amphibolite, as well as highly folded pegmatites. In one exposure along the powerline, the schist is crosscut by aplitic gneiss and strongly foliated pegmatite. The Cavendish Formation in this southern mass is primarily rustyweathering, highly feldspathic, coarsely garnetiferous schist commonly associated with calc-silicate rock. A lithologic correlation of these schists with those of the Pinney Hollow Formation, I feel, is unwarranted because the Pinney Hollow lacks calc-silicate rocks, is uniformly chlorite, muscovite, and quartz rich, and has little feldspar. I conclude that both masses of schist in the Star Hill area are the same unit and that both are interlayered with gneiss of the Mount Holly Complex.

The Cavendish Formation is reinstated here as a formal name within the Mount Holly Complex. It is correlated with the Wilcox Formation in the Shrewsbury area (Ratcliffe, 1994) and with certain schists and biotite-muscovite-kyanite-large-garnet schists (Yrs) on Ludlow Mountain that are both within the Mount Holly Complex (Ratcliffe, 1992). Retrograde variants of the large-garnet schists on Ludlow Mountain contain a muscovite-(paragonite?)-garnet-chlorite-chloritoid-relict kyanite mineral assemblage. In hand specimen and in thin section, the fine-grained muscovite schist resembles a lower grade variant of the aluminous Gassetts Schist Member of the Cavendish Formation. Aplitic granite and a kyan- 
ite-bearing pegmatite of the Mount Holly Complex crosscut the schists on Ludlow Mountain. U-Pb ages from zircon in granite that crosscuts the schists may be as old as $1,314 \pm 7 \mathrm{Ma}$ (J.N. Aleinikoff, written commun., 1997; Ratcliffe, Walsh, and Aleinikoff, 1997, table 1). In addition, the core of a muscovite megacryst from retrograde ilmenite-muscovite-chlorite-chloritoid schist on Ludlow Mountain has ${ }^{39} \mathrm{Ar}-{ }^{40} \mathrm{Ar}$ total fusion ages determined by spot-laser extraction techniques (Hames and Cheney, 1997) at between approximately 1,000 and $800 \mathrm{Ma}$. Thus, schists closely resembling aluminous rocks in the cover sequence, but mapped as Yrs within the Mount Holly Complex in the Ludlow area (Ratcliffe, 1992) and elsewhere (Ratcliffe, 1994), are Middle Proterozoic. The association of rusty-weathering, coarse-garnet schist, calc-silicate gneiss, dolomitic marble, and rusty-weathering quartz gneiss is widespread in the Mount Holly Complex and further supports the correlation of the units of the Cavendish Formation with the Mount Holly Complex of the Green Mountain massif.

New $\mathrm{U}-\mathrm{Pb}$ and $\mathrm{Pb}-\mathrm{Pb}$ ages for zircons, from a 0.25 -m-thick quartzite within the dolomite marble of the Cavendish Formation at Cavendish Gorge, meters beneath the contact with the aplitic facies of the Felchville, suggest that the quartzite and the enclosing marble may be younger than the Felchville at the site sampled. Karabinos and Thompson (1997) and Karabinos and others (1999) report $\mathrm{U}-\mathrm{Pb}$ evaporation and ion-microprobe $\mathrm{Pb}-\mathrm{Pb}$ ages of between 1,290 and $934 \mathrm{Ma}$ for zircon grains from the quartzite. If these ages are interpreted as the age of detrital grains then the rock sampled, and perhaps some of the Cavendish Formation is younger than the Felchville and not part of the Mount Holly Complex. The geologically mapped relations between the Cavendish Formation and Mount Holly, however, suggest that the Felchville is intrusive into both the paragneiss units of the Mount Holly and Cavendish throughout the quadrangle. The presence of deformed pegmatites, that are distinct from the Devonian pegmatites, in each suggests that the isotopic data may be misleading. In light of the fact that all data from zircon within the Mount Holly Complex, from either the Green Mountain massif, or from the Chester and Athens domes, have overgrowth ages ranging from 1,300 to $950 \mathrm{Ma}$, it is not at all clear that the data from the Cavendish establish a maximum age for the Cavendish Formation. Because of the strong geologic arguments for including the Cavendish Formation as part of the Mount Holly Complex, I favor that interpretation, although the age of some or all of the Cavendish should be considered uncertain. Should the new U-Pb results cited above prove correct, the age of part of the Cavendish, but not necessarily all, would be Late Proterozoic to Cambrian, and correlative to rocks of the Hoosac Formation.

\section{Intrusive rocks}

\section{Felchville Gneiss}

Granodioritic to trondhjemitic gneiss (Yfgt) forms a widespread unit within the Mount Holly Complex; finer grained variants are mapped as aplitic gneiss (Yfap). Both of these map units are well exposed at and near Felchville and herein are named formally as the Felchville Gneiss. Both units intrude and crosscut all other units in the Mount Holly Complex, including the Cavendish Formation. The dominant variety (Yfgt) is characterized by a medium- to coarse-grained texture and distinctive plagioclase augen. Overall, the unit has a granodioritic to trondhjemitic composition and contains biotite, as well as abundant secondary coarse epidote and muscovite. The microcline content is generally 0 to less than 10 percent, but may be up to 25 percent of total feldspar. Near the margin of the granodiorite gneiss, ghost-like inclusions or screens of country rock are common, whereas the interior of the unit appears massive. Near calc-silicate rocks and marbles, the aplitic gneiss (Yfap) becomes finer grained, has a low microcline content of less than 10 percent, and contains less biotite. The aplite gneiss contains xenoliths of surrounding gneiss and forms tiny lenses, dikes, or sills in the paragneiss units of the Mount Holly. In both the Yfgt and Yfap units, plagioclase forms well-twinned phenocrysts in which epidote is concentrated in the core.

Two samples of the Felchville Gneiss (Yfgt) were collected for U$\mathrm{Pb}$ dating on zircon from large roadcuts at the intersection of State Routes 44 and 106 north of Felchville and at the powerplant in Cavendish Gorge. At Cavendish Gorge, the aplitic facies of the Felchville Gneiss (Yfap) only meters thick is in contact with marble, calc-silicate gneiss, and schist units of the Cavendish Formation, and the Felchville contains xenoliths of other gneisses of the Mount Holly Complex. Conventional U-Pb data for both samples were highly discordant, scattered, and nonlinear and yielded $\mathrm{U}-\mathrm{Pb}$ ages of approximately 1,310 to $1,231 \mathrm{Ma}$. These data suggest the rocks are Middle Proterozoic. Using the ion microprobe on cores of zircons, Aleinikoff determined $\mathrm{U}-\mathrm{Pb}$ ages from unit Yfgt of $1,379 \pm 23 \mathrm{Ma}$ and from Yfap of $1,424 \pm 22 \mathrm{Ma}$. Zircons from both samples have overgrowth rims dated at approximately 1,300, 1,100 , and $950 \mathrm{Ma}$. These data indicate that the Felchville Gneiss crystallized originally at $1,424 \mathrm{Ma}$ and experienced complex thermal events subsequently in the Middle Proterozoic. Therefore, all rocks that are cut by the Felchville must be older than 1,424 Ma. Thus, the Felchville (Yfap and Yfgt) is correlated and interpreted tentatively as an intrusive resulting from an igneous event at about 1,424 Ma. Similar intrusive rocks (trondhjemite and tonalite) from the Green Mountain massif (Ratcliffe and others, 1991) have similar ages of 1,350 to $1,300 \mathrm{Ma}$. However, clear-cut intrusive relations between the tonalite and trondhjemite gneisses and the paragneisses were not observed there, and some of the trondhjemitic gneisses (the Bondville facies of Ratcliffe and others, 1991) were interpreted as metadacites. In the Cavendish quadrangle, the Felchville Gneiss clearly crosscuts the paragneiss units; therefore, the paragneiss units in the Chester dome, including some of the Cavendish Formation, should be Middle Proterozoic and older than 1,424 Ma.

The granodioritic gneiss (Yfgt) closely resembles a unit mapped informally as the gneiss of Proctor Hill in the Mount Holly area (Ratcliffe, 1992). That unit contains trondhjemitic and tonalitic gneisses, has an aplitic facies, and intrudes calc-silicate gneisses, rusty muscovite-chlorite-chloritoid schists, and amphibolites of the Mount Holly Complex. Similar relations occur in the Weston quadrangle (Ratcliffe and Burton, 1996). In both areas, the rock relations are nearly identical with those in the Cavendish quadrangle.

\section{Other gneisses and pegmatites}

Coarse-grained granitic gneiss and pegmatite are widespread in the Mount Holly Complex in the Cavendish quadrangle. Masses of granitic gneiss (Ygg) contain large microcline crystals 1 to $2 \mathrm{~cm}$ long and a texture that varies from pegmatite to medium grained. Two of the largest masses are east of Star Hill and on the hills east and south of South Reading. Small pods of pegmatite 0.5 to $10 \mathrm{~m}$ thick appear in all of the units of the Mount Holly Complex including the Cavendish Formation. These pegmatites are now chloritized, highly deformed, and clearly predate the regional $\mathrm{S}_{2}$ foliation. Excellent pegmatite exposures occur in the schists of the Cavendish Formation on the eastern and western walls at the upper end of Cavendish Gorge about $150 \mathrm{~m}$ downstream from the dam. These pegmatite pods, which are 0.5 to $1 \mathrm{~m}$ in diameter, contain ghosts 
of coarse-grained biotite and hornblende that have been totally replaced by fine-grained biotite and chlorite.

The age of these pegmatites is unknown, but similar pegmatites on Ludlow Mountain intrude quartzites, calc-silicate gneisses, and aluminous kyanite-garnet schists (now retrograded largely to muscovite-chlorite-chloritoid-quartz schists). Discordant $\mathrm{U}-\mathrm{Pb}$ ages on zircon indicate the pegmatites may be approximately $1,200 \mathrm{Ma}$ (J.N. Aleinikoff, written commun., 1991). These old, highly deformed pegmatites in the Cavendish quadrangle are notably different from the younger Devonian pegmatite and two-mica granites that crosscut the regional $S_{2}$ foliation; the younger pegmatites are notably poor in potassium feldspar and have a biotite-muscovite granodiorite composition. The Devonian pegmatites and granite dikes crosscut the strong $S_{2}$ foliation and are weakly foliated in the southeastern part of the map in the Pine Hill area where $F_{4}$ folds are well developed. Elsewhere, they are nonfoliated and mildly folded by only the $F_{5}$ folds.

In summary, granitic and trondhjemitic intrusive rocks are abundant in the Mount Holly Complex in the Cavendish quadrangle. $\mathrm{U}-\mathrm{Pb}$ data from here and supporting data from the Ludlow area suggest that granitic activity occurred at various times between approximately 1,442 and 1,200 Ma. Evidence for a distinct intrusive event at about $1,000 \mathrm{Ma}$ is not well documented from the Green Mountain massif or from the Chester dome, although some data (Ratcliffe and others, 1991) from this area suggest the possibility of metamorphic overgrowths on zircon at about 1,000 Ma and again at $950 \mathrm{Ma}$.

\section{Mantle rocks}

The mantle rocks of the Chester dome beneath the Waits River Formation have been interpreted in various ways by Doll and others (1961) and Thompson and others (1990, 1993) (fig. 7). According to Thompson and others (1993), the ascending sequence of rocks from the Middle Proterozoic gneisses of the core are (1) slabby gneiss, including marble, calc-silicate gneiss, and augen gneiss of the Bull Hill Gneiss, (2) feldspathic granofels of the Hoosac Formation, (3) aluminous and carbonaceous schists of the Pinney Hollow and Ottauquechee Formations that are overlain by interlayered mafic and felsic volcanic rocks and metasedimentary rocks of the Hawley Formation of Massachusetts. Significant differences between Doll and others (1961) and Thompson and others (1993) are (1) including the carbonaceous schist of the Missisquoi Formation in the Ottauquechee Formation, (2) including the Barnard Volcanic Member of the Missisquoi in the Hawley Formation above an unconformity, and (3) creating a marginal zone of slabby gneisses of uncertain correlation beneath the Hoosac Formation that might possibly contain Hoosac and older rocks. In both the 1961 and 1993 interpretations, the map units form parallel, concentric bands uniformly distributed about the northern closure of the dome.

In contrast, the present map shows the mantle units beneath the Waits River Formation as highly irregular. In addition, rocks identified as Hoosac, Pinney Hollow, and Ottauquechee by Thompson and others (1993) are absent or correlated differently (fig. 7). Rocks corresponding to the Hoosac Formation and augen gneisses of the Bull Hill Member of the Cardinal Brook Intrusive Suite are absent in my interpretation. Also, 1 have assigned amphibolite (Oma) and green phyllonitic schist (Omgs) to the Moretown Formation.

\section{Moretown Formation}

The Keyes Mountain thrust fault separates the middle Paleozoic core rocks of the Chester dome from the overlying mantle of
Paleozoic cover rocks. The base of the cover section has a highly mylonitic zone of very finely foliated rocks and numerous small discontinuous bodies of different rock types that are too small to map at the scale of 1:24,000. Pods, lenses, or fault slivers of amphibolite (Oma), coarse garnet-plagioclase granofels (Omg), and phyllonitic schist (Omgs) are dispersed along the fault contact, and they comprise a thin, highly deformed band above the fault.

Although an amphibolite unit (Oma) is mapped as a continuous unit along much of the contact, in reality, it is a zone of intermixed thin amphibolite and phyllonitic schist (Omgs). Locally, the two units are separable, and slivers or infolds of amphibolite and schist butt against the fault. The amphibolite (Oma) is highly sheared, black to dark green, and contains thin epidote laminae near the fault. Elsewhere, less deformed amphibolite occurs interlayered or as fault slivers within the feldspathic granofels (Omg) and schist (Omgs) units. In some exposures, the contact between the highly folded amphibolite and other rocks is a fault contact that truncates older folds and schistosity in both plates. These faults, in turn, are highly folded.

The green phyllonitic schist unit (Omgs) contains thin beds of pinkish coticule 1 to $2 \mathrm{~m}$ thick near contacts with amphibolite and lenses of feldspathic granofels. The overlying feldspathic granofels and schist (Omfg) also contains coticule, as well as coarse clots and sprays of chlorite and actinolite and tan feldspathic quartzite. These rocks are typical of the Moretown Formation mapped throughout southern Vermont (Ratcliffe and others, 1992). Beds of dark-gray, carbonaceous, rusty-weathering schist (Omb) are interbedded within and particularly at the top of the feldspathic granofels and schist unit (Omfg). A discontinuous, rusty schist (Omr) near the base(?) of the Omfg unit resembles the large mass of rusty carbonaceous schist $(\mathrm{Omb})$; both may be the same unit that was repeated by folding. White to tan feldspathic quartzite (Omfq) is common within the Omfg unit and is shown where thick enough.

Rusty, slabby, carbonaceous biotite schist (Omb) forms a distinctive unit overlying the feldspathic granofels and schist unit (Omfg). A discontinuous zone of fine-grained, carbonaceous phyllite having small garnets may occur near the contact. The contact between Omb and Omfg may be sharp, may be a fault, or may be gradational. A predominantly rusty schist within the Omb unit contains minor dark-gray- to steel-gray-weathering beds of vitreous quartzite or slightly gritty quartzite (Ombq). The Omb unit includes lenses of talc schist and talc-carbonate schist near Hammondsville and on Keyes Mountain. These lenses probably reflect internal faults along which slivers of ultramafic rock $(\mathrm{OZu})$ were trapped. Near the ultramafic belt is a large lens or sliver of well-laminated, pinstriped feldspathic quartzite (OmI). The Omb unit occupies the same structural position as the black schist associated with the Proctorsville ultramafic belt west of the Proctorsville syncline (fig. 1). On Keyes Mountain, coarse- to medium-grained dioritic amphibolite and finegrained, well-foliated plagioclase-epidote-hornblende amphibolite (Omd) is associated with pods of talc-carbonate rock. Amphibolite is mapped as unit Oma along the contact between (Omfg) and (Omgs).

The overall distribution of units within the Moretown appears to be stratigraphic and progresses upward from Omgs to Omfg to Omb. However, repetition of units, like Omb lower in the section and Omfg higher in the section, suggest complication either by internal, intrafolial folding or internal faulting. The presence of exotic talc schists and fault-bound amphibolites supports repetition by faulting. This faulting may be older than the regional foliation associated with the Keyes Mountain thrust fault and probably is Taconian. Near the eastern border of the map on Rowe Hill, the Omb unit is in contact with the basal amphibolite (Oma) and the 
intervening Omfg and Omgs units are absent, perhaps cut out by internal faults above the Keyes Mountain fault. Numerous small faults and faulted folds occur within this belt. The Omfg, Oml, Omfq, Oma, and Omg units are typical of the Moretown units mapped to the west in the Plymouth (Walsh and Ratcliffe, 1994) and Ludlow (N.M. Ratcliffe and G.J. Walsh, unpub. mapping, 1994) quadrangles. The rusty schist unit (Omb) has been assigned to rocks mapped as the Cram Hill Formation in the Ludlow quadrangle by Doll and others (1961) and as the Ottauquechee Formation in the Pinney Hollow-Ottauquechee-Hoosac sequence by Thompson and others (1993) (fig. 7). However, the Pinney Hollow-Ottauquechee-Stowe sequence does not match the stratigraphic stacking of the Omb unit above the other Moretown rock units mapped here in the mantle sequence of the Chester dome. Moreover, recent remapping of the type section of the Ottauquechee Formation and its extension southward (Walsh and Ratcliffe, 1993) substantiates that the Ottauquechee and Moretown rocks are different. On the other hand, rusty carbonaceous schist is widely developed in the Moretown Formation of southern Vermont (Ratcliffe and others, 1992) and was called the Whetstone Hill Member of the Missisquoi Formation by Thompson (1950).

The section of rocks between the Keyes Mountain thrust fault and the feldspathic granofels and schist $(\mathrm{Omfg})$ was previously mapped as Pinney Hollow, Ottauquechee, and Stowe Formations, undivided (O€u of Doll and others, 1961) (fig. 7). None of the rocks in the Cavendish area bear a strong resemblance to the Pinney Hollow or Ottauquechee rocks, but some of the chloritebiotite muscovite schists in the Omgs unit here may correlate with garnet-poor units of the Stowe in the Plymouth quadrangle (Walsh and Ratcliffe, 1994).

Rocks immediately beneath the Keyes Mountain thrust fault were mapped as the Hoosac Formation and underlying Bull Hill Gneiss by Doll and others (1961), but neither of these units is present in this area of the map. Rocks older than the Moretown on the eastern flank of the Green Mountain massif (the Tyson, Hoosac, Pinney Hollow, and Stowe Formations) were cut out by the Keyes Mountain thrust fault, which places younger rocks on older rocks. Such nonconventional relations are possible in areas where thrust faults cut upwards through already overturned rocks. The intrusive Bull Hill Gneiss (Ratcliffe, 1991) had been interpreted as intercalated within the Hoosac Formation by Thompson and others (1993). However, the Bull Hill Gneiss Member of the Cardinal Brook Intrusive Suite is dated by U-Pb zircon age of 955 $\mathrm{Ma}$ and therefore would require that the Hoosac Formation be older than $950 \mathrm{Ma}$. Potassium-feldspar augen gneisses typical of the Bull Hill Gneiss are absent in the Cavendish area. However, porphyroclastic plagioclase augen gneiss derived from the granodiorite gneiss unit (Yfgt) is present and may have been mistaken as Bull Hill $G$ neiss by previous workers.

\section{Barnard Gneiss and granofels}

The Barnard Gneiss comprises a poorly exposed, narrow belt of possibly metavolcanic rocks or a layered-sill complex above the Moretown Formation. The Barnard Gneiss (Obmf) is a well-layered, dark-gray hornblende-plagioclase amphibolite interlayered with light-gray to pinkish-gray-weathering hornblende felsic gneiss. Both layers commonly are 1 to $100 \mathrm{~cm}$ thick and alternate or pass along strike into masses of amphibolite lacking the felsic layers. The contact with the underlying Moretown is not exposed. The thinness of this unit here is remarkable, for in the Plymouth and Ludlow quadrangles just west of the Proctorsville syncline, the Barnard Gneiss is 1 to $2 \mathrm{~km}$ thick. There, at least 70 percent of the Barnard is a light-gray to white-weathering, medium-grained, massive trondhjemite gneiss that probably is intrusive (Walsh and Ratcliffe, 1994) and is totally absent in the Cavendish quadrangle. The thin Barnard Gneiss section here may be the result of erosion or the absence of the abundant intrusive rocks.

Nomenclature for the Barnard Gneiss (Ratcliffe, Armstrong, and Aleinikoff, 1997), developed since preparation of this report, restricts the name Barnard Gneiss to meta-intrusive trondhjemitic and tonalitic gneiss northwest of the Chester dome and to local occurrences along the eastern margin of the dome. In Vermont south of the Chester dome the intrusive rocks correlative with the Barnard belong to the North River Igneous Suite of Armstrong (1994). All of these plutonic rocks occur within the Moretown or Cram Hill Formations and establish minimum ages for deposition of these units.

$\mathrm{U}-\mathrm{Pb}$ ages of zircon from intrusive trondjemite and tonalite from the Barnard and North River Igneous Suite have been determined by J.N. Aleinikoff from 3 localities at $496 \pm 8 \mathrm{Ma}, 486 \pm 3 \mathrm{Ma}$, and $462 \pm 6 \mathrm{Ma}$ (Ratcliffe, Armstrong, and Aleinikoff, 1997). An additional U-Pb zircon age of $471 \pm 4$ Ma has been determined by Scot Sampson for Barnard Gneiss near its type locality (Karabinos and others, 1998). In addition, zircon from a thin felsic layer, interbedded with black schists and feldspathic and coticule-bearing granofels from the Springfield quadrangle yielded a U-Pb upper intercept age of $484 \pm 4 \mathrm{Ma}$ (Ratcliffe, Armstrong, and Aleinikoff, 1997). The dated rock, interpreted as a felsic volcanic, is interbedded within what has been mapped as Ombs in this quadrangle and dates the age of deposition of the upper part of the Moretown Formation in the Chester quadrangle. Ratcliffe, Armstrong, and Aleinikoff (1997) now regard the Ombs unit of the Chester quadrangle and the dated volcanic layer from Springfield as correlative of the Cram Hill Formation of central Vermont.

A thin, discontinuous, unnamed unit of calcareous volcaniclastic and feldspathic granofels (DScv) overlies the Barnard Gneiss in this quadrangle. This unit contains 1 - to $10-\mathrm{cm}$-thick interlayered, finely laminated, actinolitic calcite-chlorite marble; hornblende-plagioclase-quartz felsic gneiss; and epidote-hornblende-calcite greenstone. Near the top of the unit are beds of dark-blue to blue-gray siliceous marble and lustrous, carbonaceous, small-garnet schist, or zones of interbedded rusty amphibolite and gray quartzite (DSaq). The total unit is less than $8 \mathrm{~m}$ thick and is interbedded with the base of the Waits River Formation. The DScv unit is interpreted as a zone of reworked detritus derived from the underlying Barnard Gneiss; a nonconformity or local disconformity separates the two.

\section{Waits River Formation}

Dark-gray to silvery-gray carbonaceous phyllite or schist of the Waits River Formation overlies the Barnard Gneiss and the unnamed granofels unit (DScv). The Waits River contains distinctive, punky, brown-weathering, deep-blue-gray quartzose marble beds as much as $10 \mathrm{~m}$ thick, but commonly less than $0.5 \mathrm{~m}$ thick, which extend to the base of the formation. These marble beds are so poorly exposed, the distinction could not be mapped between the Waits River Formation and the Northfield Formation, a marblefree carbonaceous schist. The age of the Waits River is uncertain. Aleinikoff and Karabinos (1990) obtained a U-Pb age of $423 \pm 6 \mathrm{Ma}$ from zircon in a dike that cuts the Standing Pond Volcanics near Springfield; the Standing Pond is thought to overlie part or all of the Waits River. Hatch (1991) and Hueber and others (1990) report Early Devonian plant fossils in the Gile Mountain Formation above the Waits River. These constraints would place the Waits River Formation between Middle Silurian and Early Devonian. 


\section{INTRUSIVE ROCKS OF THE CORE AND MANTLE}

\section{Devonian granite dikes and pegmatite}

Relatively straight-walled, narrow dikes 0.5 to $5 \mathrm{~m}$ thick of characteristically unfoliated, fine-grained biotite-muscovite granite $(\mathrm{Dg})$ or pegmatite $(\mathrm{Dp})$ crosscut highly foliated rocks in the core of the Chester dome. In the Pine Hill area near the southeastern corner of the map, some granite and aplite dikes crosscut the schistosity and foliation in the Cavendish Formation ( $\mathrm{Ycfs}$ ), but the dikes are weakly foliated parallel to axial surfaces of late northeast-trending folds of the schistosity. All Devonian dikes crosscut the dominant foliation associated with major deformation in the dome but are weakly folded by the latest north-south folds. The above characteristics distinguish Devonian dikes from Middle Proterozoic pegmatites found in the Cavendish and other units of the Mount Holly Complex.

\section{Cretaceous dikes and intrusives at Little Ascutney Mountain}

Numerous lamprophyre, diabase, trachydacite, and felsite dikes related to the large intrusive stock at Little Ascutney Mountain are the youngest rocks in the area. The dikes commonly are associated with pronounced jointing in the country rocks parallel to their walls. Chemical weathering of the dikes and physical weathering of this highly jointed country rock commonly result in narrow sharp-walled valleys where the dikes once were. Near the margin of the stock at Little Ascutney Mountain, shallow-dipping mafic and felsic sills and dikes parallel the concentric dike sheets. This form of intrusion and the presence of very fine grained, spherulitic(?) felsite dikes suggest very shallow intrusion depths (Balk and Krieger, 1936).

A large, steep-walled composite stock of gabbro, diorite, and syenite intrudes the Mount Holly Complex along the central eastern side of the map. This stock is the western extension of the much larger Mount Ascutney pluton described by Daly (1903). The contact relations and distribution of rock types have been compiled from Daly (1903), Chapman and Chapman (1940), and Schneiderman (1989). Foland and others (1985) studied the petrology, geochronology, and isotopic characteristics of the pluton. They concluded that the pluton consists of earlier gabbroic rocks that were contaminated by assimilation of country rock in varying but high degrees and later syenitic and granitic rocks that have little contamination. Nearly concordant $\mathrm{K}-\mathrm{Ar},{ }^{39} \mathrm{Ar}-40 \mathrm{Ar}$, and $\mathrm{Rb}-\mathrm{Sr}$ whole rock isochron ages on biotite from a diorite to granite suite are clustered at $122 \pm 1.5 \mathrm{Ma}$ and indicate the intrusives were contemporaneous and cooled quickly. Therefore, Foland and others (1985) and Hubacher and Foland (1991) concluded the rocks were intruded at a shallow crustal level in the Cretaceous. Inclusions of trachytic volcanic rocks in all rock types also indicate a shallow intrusion (Chapman and Chapman, 1940). Although Schneiderman (1989) proposed that the plutons may have been intruded at depths of 5.8 to $14.5 \mathrm{~km}$, these depths may be excessive because of the rapid closure of the argon and Rb-Sr systems at $122 \mathrm{Ma}$. At depths of $14 \mathrm{~km}$ in the Cretaceous, temperatures would have been approximately $280^{\circ} \mathrm{C}$ if a geothermal gradient of $20^{\circ} \mathrm{C}$ per kilometer were assumed. Regional cooling ages for biotite and microcline in the country rocks beyond the contact aureole range from $345 \mathrm{Ma}$ to $310 \mathrm{Ma}$, respectively (Harrison and others, 1989). Regional cooling below approximately $250^{\circ} \mathrm{C}$ (the blocking temperature of microcline) had occurred approximately 188 m.y. before the intrusion of the Mount Ascutney pluton. Therefore, depths of intrusion as great as $14.5 \mathrm{~km}$ seem unlikely. In addition, regional fission-track ages on apatite are about $90 \mathrm{Ma}$
(Zimmerman and others, 1975), which suggests that at that time temperature had cooled to about $100^{\circ} \mathrm{C}$ at a depth of about $4 \mathrm{~km}$.

Gravity and aeromagnetic modeling of the intrusive complex at Mount Ascutney by Daniels (1990) showed the lack of a strong positive gravity anomaly and aeromagnetic gradients of a shallowfloored feature over the gabbro-diorite stock. He suggests the gabbro-diorite body is inclined eastward as a stepwise intrusion fed from the main feeder at Mount Ascutney.

\section{STRUCTURAL GEOLOGY}

\section{Method of analysis}

The structural geology of the Cavendish quadrangle may be viewed as either extremely complex, or relatively straightforward. Previous workers portrayed complex structures demonstrated by intricate map patterns that involved repetitions of basement and cover rocks and the inversion of the rock sequence (see figs. 1, 35). The hypothesis (Thompson, 1950; Rosenfeld, 1968; Thompson, Rosenfeld, and Downie, 1986) that the basement and cover rocks were involved in recumbent Acadian isoclinal folds can be tested by mapping the units in the core of the dome. A geometric requirement of the isoclinal and recumbent fold model is that the axial surfaces of the proposed nappe-stage folds are the actual planes of symmetry about which the rocks are repeated, as, for example, along the axial traces shown in figures 1 and 3 . In order to evaluate this, 1 mapped marker units in the Mount Holly Complex and the pattern of Acadian foliation. The form line map (fig. 8) of the dominant foliation shows the relation between amplitude and orientation of potential nappe-stage folds. Measurements of the dominant regional $\mathrm{S}_{2}$ foliation in older rocks and the schistosity in Silurian and younger rocks were used to construct the form line map. The form lines, therefore, are older than any of the crenulation cleavages and warping associated with younger folds, but the form lines are deflected, or warped, by the younger events.

\section{Fold generations and cleavage development}

Axial traces of five generations of folds are shown on the geologic map. The oldest folds $\left(F_{1}\right)$ caused repetition of gneiss and schist units in the core of the dome. These folds trend generally northeast. Both gneissic layering and coarse schistosity are highly folded and generally dip steeply to the southeast or northwest. In most outcrops, the old compositional gneissic layering or schistosity is difficult to determine because of numerous short-wavelength $F_{2}$ folds. The double strike-line symbol shows the generalized strike and dip of the old gneissosity. Upright $F_{1}$ folds having a northeasttrending axial surface and plunge were observed at four localities. The $F_{1}$ folds are refolded by younger $F_{2}$ folds and are strongly cross foliated by the dominant schistosity $\left(\mathrm{S}_{2}\right)$.

If the Cavendish Formation is younger than the Mount Holly Complex, the $\mathrm{F}_{1}$ folds could be either Taconian or Acadian. The correspondence of pegmatites within the Mount Holly Complex with trends of $F_{1}$ fold limbs and the discordance with folds and structures in the mantle rocks and the lack of $F_{1}$ folds involving the 955-Ma-old Bull Hill Gneiss Member of the Cardinal Brook Intrusive Suite in the Chester and Saxtons River quadrangles all suggest a Grenville age for the $F_{1}$ folds.

An intensely developed regional foliation in both basement and cover rocks parallels the margin of the Chester dome and the overlying Waits River Formation. Because of this concordance, the $\mathrm{S}_{2}$ foliation is interpreted as Acadian. However, the foliation in the core of the dome may be pre-Acadian or Taconian. Regional relations (Ratcliffe and others, 1992; Walsh and Ratcliffe, 1994; Ratcliffe, 1993) suggest this is the case outside the dome. Here, 
the schistosity is termed the $\mathrm{S}_{2}$ foliation, and the attendant folds that have this foliation as the axial surface are termed the $F_{2}$ folds, assuming that the pre-Silurian rocks may have a composite of Taconian and Acadian foliation. On the map this $S_{2}$ foliation is shown by a solid triangle on the foliation symbol. The $\mathrm{S}_{2}$ foliation dips steeply to the northwest and west along the western limb of the Chester dome, but the $\mathrm{S}_{2}$ foliation swings east-west and dips gently to the north at the northern end of the dome. In the core of the dome, the $\mathrm{S}_{2}$ foliation may cross lithologic unit contacts within the Mount Holly Complex at a high angle, unless the units were rotated into conformity on limbs of the $\mathrm{F}_{2}$ folds.

Lineations produced along the intersection of $\mathrm{S}_{2}$ foliation and older $F_{1}$ gneissosity or schistosity parallel the hinge lines of folds that plunge at high angles to the strike of the $S_{2}$ foliation. Many $F_{2}$ folds are reclined, meaning that the reclined fold has a hinge line that plunges down the dip of the axial surface at a high rake angle. The term reclined does not refer to the gentleness of dip of the axial surface, as in an inclined or recumbent fold. Along the western limb of the dome, the $\mathrm{F}_{2}$ fold hinge lines plunge steeply to the northwest, whereas around the northern end of the dome, these plunges vary from northwest to north to northeast.

The form line map (fig. 8) produced from the strike and dip pattern of $\mathrm{S}_{2}$ foliation in the core and $\mathrm{S}_{2}$ schistosity in the cover rocks of the dome demonstrates two important things: (1) the $S_{2}$ foliation clearly parallels the Keyes Mountain thrust fault and (2) the $\mathrm{S}_{2}$ foliation does not produce large amplitude deflections between the Cavendish Formation and other units in the Mount Holly Complex. These observations are important in determining the presence of fold nappes in the Mount Holly Complex.

The sense of rotation of minor $F_{2}$ folds is variable and is not systematic in a way that would be useful in deducing stratigraphic tops or kinematic drag sense of larger folds. This generally is the case where foliations transect older folds and irregularly oriented layers. The intensity and amplitude of the $\mathrm{F}_{2}$ folds increase near the Keyes Mountain thrust fault and are less within the core.

Three, possibly four, additional fold sets were imposed on the rocks after formation of the $\mathrm{S}_{2}$ foliation. Each later fold set is expressed by a strong to weak axial-planar crenulation cleavage. The $\mathrm{S}_{2}$ form line map (fig. 8) shows the trend of the $\mathrm{S}_{2}$ foliation and subsequent folds of that reference surface. Local deflections identify the younger folds that may or may not deflect the more steeply dipping lithologic contacts. The later $F_{3}, F_{4}$, and $F_{5}$ folds produce the composite form of the Chester dome. These generally north-plunging folds are the dome-stage folds recognized by Thompson (1950) and Rosenfeld (1968).

Folding of older reference surfaces, such as the steeply dipping gneissosity associated with the $F_{1}$ folds, may not have deflections if the units have a subvertical dip. Map deflection of contacts is an expression of the component of the fold amplitude in the plane of the map. For this reason, steeply dipping lithologic contacts may not show major deflection where $\mathrm{F}_{3}$ or younger folds cross. The gently dipping $S_{2}$ foliation is, however, at a high angle to the later folds and serves as a better reference surface for showing subsequent folding related to formation of the dome.

Several east-west to northwest-trending $F_{3}$ folds deflect the form lines shown in figure 8 . These $F_{3}$ folds are generally upright to overturned to the southwest. A series of northeast-trending, later crenulate $\mathrm{F}_{4}$ folds with southeast-dipping axial surfaces are developed near the northeastern border of the map. The last set of folds to form, $F_{5}$ folds, are very weakly developed, north-trending, and have a subvertical crenulation cleavage.

The $F_{2}$ and younger structures are generally present in the mantle rocks of the dome, as well as the Silurian and Devonian rocks farther from the dome. Within the Moretown Formation, the $\mathrm{S}_{2}$ foliation is superposed on an older schistosity that is tightly folded about $F_{2}$ axial surfaces. Everywhere both foliations dip away from the dome and are parallel to the dip of the Keyes Mountain thrust fault. The strong folding within the Moretown Formation and along the Keyes Mountain fault probably is Acadian, but an older penetrative foliation associated with synmetamorphic faults is present within the Moretown. Earlier, Taconian movement on the Keyes Mountain fault or similarly oriented surface cannot be discounted and seems likely.

Structures within the Waits River Formation must be younger than Early Devonian and, therefore, must be related to the Acadian orogeny. Foliation and bedding are parallel in the Waits River, and Acadian $F_{1}$ folds can be seen only rarely. A well-exposed bed of limestone (DSwrl) in the northwestern part of the map shows an $F_{1}$ fold plunging $8^{\circ}$ northeast. Multiple crenulation cleavages are common within the Waits River. On the northwestern limb of the dome, one crenulation cleavage dips northwest, whereas a second crenulation cleavage dips steeply southeast. Hinge lines of both folds trend northeast and plunge shallowly northeast or southwest, generally coaxial with $F_{1}$ folds. On the northern closure of the dome, a crenulation cleavage and the $\mathrm{S}_{2}$ foliation are folded and dip gently to moderately steeply to the north-northeast. Another unfolded, north-south, upright crenulation cleavage is present that clearly can be correlated with the $\mathrm{F}_{5}$ crenulation cleavage in the core of the dome. North of Sheddsville Hill, amphibolite and felsic gneiss of the Waits River Formation (DSwra and DSwrf) contain two nearly coplanar Acadian axial surfaces. The older schistosity and axial surface dip northeast and contain fold hinges that plunge east and southeast. Superposed on these folds is a strong second generation crenulation cleavage with an axial surface also dipping to the northeast. Hinge lines of these folds plunge to the northwest. The amphibolite unit (DSwra) may outline the axial trace of a refolded early syncline. Later northwest-plunging folds are second generation Acadian folds.

Just north of the quadrangle, a crenulation cleavage and $\mathrm{S}_{2}$ foliation in the Waits River Formation have different strikes but parallel dips to the north. The lineation formed at their intersection is parallel to the hinge lines of folds that plunge northeast, north, and northwest. At the western closure of the amphibolite unit (DSwra) on the hills west of Spear Cemetery in the Woodstock South quadrangle, second generation folds plunge $7^{\circ}$ to $10^{\circ}$ north and northwest.

These observations may be regionally important. Doll and others (1961) had identified the amphibolite unit (DSwra) as belonging to the Standing Pond Volcanics and interpreted it as facing downward in a northwest-plunging antiform of a nappe beneath the Waits River. However, as noted above, both northwest and southeast plunges are present in the amphibolite near its closure. The northwest plunges developed after the $\mathrm{S}_{1}$ schistosity, and the earlier plunges suggest the possibility of an early $F_{1}$ southeast-plunging syncline in the amphibolite. In such an interpretation, the DSwra unit structurally and stratigraphically overlies the Waits River.

\section{Discussion of cross sections}

The roof and floor of the Chester dome in the Cavendish quadrangle are defined by the Keyes Mountain and Hawks Mountain thrust faults, respectively. The form line map (fig. 8) illustrates the intense $\mathrm{S}_{2}$ foliation, which parallels both faults and is well developed in the core of the dome. The amplitude of the Chester dome can be estimated from the form line map because the internal $S_{2}$ foliation is not highly deformed by later folding. This foliation has been projected into the cross sections, and used to determine the 


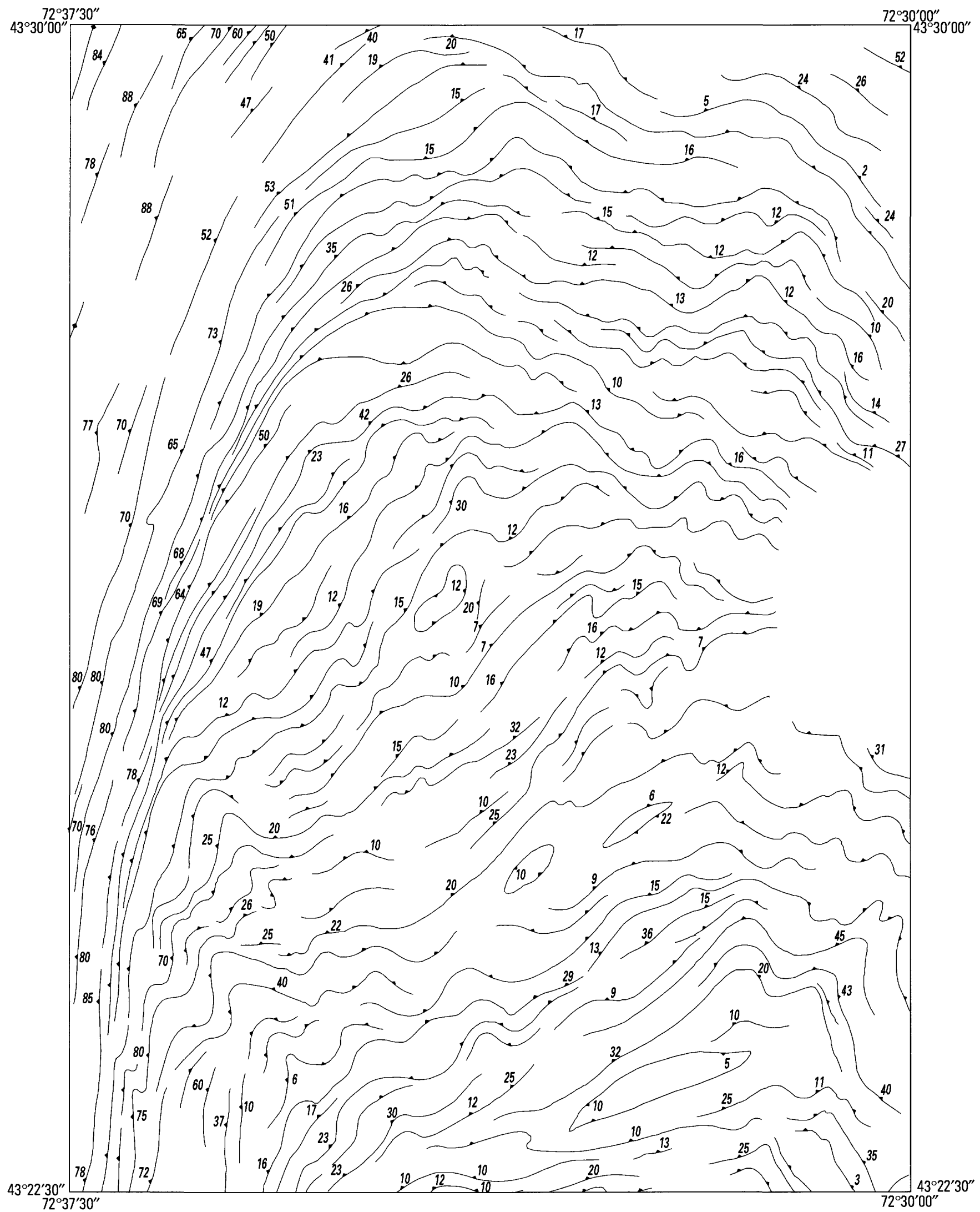

Figure 8.-Form line map showing strike and dip of the dominant regional foliation $\left(\mathrm{S}_{2}\right)$ in rocks in the Cavendish quadrangle. Deflections of the form lines demonstrate the trend and plunge of younger folds. Northwest- and northeast-trending $F_{3}$ and $F_{4}$ folding warped the form lines before $F_{5}$ folding. 
vertical distance of about $2.5 \mathrm{~km}$ between the Hawks Mountain and Keyes Mountain thrust faults. This construction defines both the amplitude and form of the dome itself.

Marker units within the core of the dome are approximately at right angles to the internal $\mathrm{S}_{2}$ foliation. These units trend diagonally northeast across the dome and show little effect of the doming. These marker units record flattening, not shortening of the domal stage because of their subvertical orientation. However, the mantle units, most notably the Waits River Formation, and the $\mathrm{S}_{2}$ foliation pattern within the dome uniquely define the form of the dome.

The continuity of the major belt of granodioritic Felchville Gneiss (Yfgt) in the map and four east-west cross sections is particularly apparent, even though confined within the $\mathrm{S}_{2}$ form lines. The Felchville Gneiss must extend from the floor (the Hawks Mountain thrust) (section $C-C$ ) to the roof (the Keyes Mountain thrust) (sections $A-A^{\prime}$ and $\left.B-B\right)$ of the Chester dome.

The general pattern of older upright folds is substantiated by the subvertical minor folds observed in several areas. These folds plunge gently northeast and are older than the $S_{2}$ foliation, perhaps Grenvillian. The upright form of some older fold closures and the amplitude and distribution of $\mathrm{S}_{2}$ folds in the Mount Holly Complex are shown in the cross sections. In particular, most of structure shown in section $B-B^{\prime}$ predates the $S_{2}$ event in the Cavendish Formation and other Mount Holly units north of the Star Hill area.

Structures in the mantle above the Keyes Mountain fault (section $A-A)$ are highly folded and refolded, especially in the lower units of the Moretown Formation within a 0.5 -m-thick zone adjacent to the fault. Lack of complex refolding in the overlying Waits River Formation or of the upper Moretown contact with the Barnard Gneiss or Waits River Formation could indicate that much of the folding and shearing is older than the Waits River or that the strain was concentrated on or near the Keyes Mountain fault. An accurate projection of Moretown units in the cross sections is not possible because of the irregular and heterogeneous deformation within the Moretown. However, from the continuity of the Moretown and the absence of other rocks in the hanging wall of the Keyes Mountain thrust, the Moretown is assumed to form the mantle overlying the Keyes Mountain fault above the crest of the Athens dome to the south.

\section{Cretaceous(?) brittle faults}

Well-defined brittle faults are rare in the area, but numerous prominent, highly jointed outcrops and a few minor faults are near the Mount Ascutney pluton. Two normal faults, which have northerly strikes and northwest or southeast dips, have been mapped in the knobs about $0.5 \mathrm{~km}$ south of Robinson Hill. A distinctive Cretaceous felsite sill has been dropped at least $1 \mathrm{~m}$ along the southern, southeast-dipping fault. A pair of unmapped normal faults trend N. $20^{\circ} \mathrm{E}$. and dip approximately $70^{\circ}$ northwest and southeast $1 \mathrm{~km}$ south of Little Ascutney Mountain. On the eastern side of North Branch Brook at Amsden is a 0.6-m-wide shatter zone filled with vein quartz that strikes $\mathrm{N}$. $10^{\circ} \mathrm{W}$. and dips $56^{\circ} \mathrm{NE}$. A similar zone of quartz veins and vertically fractured rocks occurs in the Waits River Formation in a small prospect on the eastern side of Willow Brook $1 \mathrm{~km}$ west of Sheddsville Hill. Slickensides plunge about $10^{\circ}$ northwest on a N. $45^{\circ} \mathrm{W}$. subvertical fracture surface. These features are associated with the Cretaceous plug at Mount Ascutney, and the fault that offsets one felsite sill is $122 \mathrm{Ma}$ or younger.

\section{Summary}

The oldest folds $\left(\mathrm{F}_{1}\right)$ are in the core of the Athens dome. The age of the $F_{1}$ folds is unknown, but probably is Grenvillian. They are comparable to folds found in the Green Mountain massif to the west (Ratcliffe, 1992). They were transected by a regional internal foliation $\left(\mathrm{S}_{2}\right)$ during the Acadian orogeny. However, in this interpretation, mappable folds and foliations attributed to the Taconian orogeny are missing. If, indeed, the $\mathrm{F}_{1}$ folds are Taconian, the older Grenville structure must no longer be recognizable in these rocks. Detachment between Acadian deformation in the cover rocks above the Keyes Mountain fault and core rocks of the dome is likely, but Taconian faulting also is possible here.

Evidence of Acadian nappe-stage folds is not evident in the core rocks mapped here. It is important to note that the nappe interpretation is essentially geometric and independent of the age of the Cavendish Formation. It is clear that the $\mathrm{S}_{2}$ foliation within the dome cannot be the axial surface of Acadian nappes because the map units trend at high angles across the $\mathrm{S}_{2}$ foliation. The elimination of mantle rocks older than the Moretown Formation around the dome suggests thrust faulting of a complicated, perhaps inverted, section of rocks that, perhaps, moved from a different structural setting entirely. The Moretown Formation is thought to be allochthonous and emplaced originally by Taconian thrusting of an accretionary wedge over Laurentian crust and cover rock (Stanley and Ratcliffe, 1985). This scenario thrusts tectonic cover rocks from the subduction zone to higher structural levels in the Taconian, or Acadian, or both. In this case younger rocks from the original (subduction) hanging wall could be thrust over older rocks.

Doming of all rocks came after the development of the regional $\mathrm{S}_{2}$ foliation and the $\mathrm{S}_{3}$ crenulation cleavage in the Waits River Formation. The Waits River also has prominent late north-south $\mathrm{F}_{5}$ folds, as well as northeast-trending $\mathrm{F}_{4}$ folds. Doming could have been produced by cross folding on the $F_{4}$ and $F_{5}$ folds. The $F_{3}$ folds in the core rock probably correlate with the $\mathrm{S}_{3}$ crenulation cleavage in the Waits River.

\section{METAMORPHISM AND CHRONOLOGY OF TECTONIC EVENTS}

Rocks of the Cavendish area were affected by regional metamorphism at garnet to staurolite-kyanite grade in the Acadian (Thompson, 1950; Downie, 1982; Armstrong and Tracy, 1991). Rocks in the core of the dome are believed to be at kyanite grade (Doll and others, 1961), but confirmation of this is difficult because aluminous-rich rocks that might contain staurolite or kyanite are rare. The occurrence of kyanite appears to be limited to exposures of the more aluminous Gassetts Schist Member of the Cavendish Formation. Much of the mantling Moretown Formation contains biotite, muscovite, and plagioclase, \pm tremolite, and hornblende, and the Waits River Formation is notably calcareous and rather potassium-rich rock and not of suitable bulk composition to contain kyanite at these grades. Despite the aluminous nature of the Gassetts, kyanite generally occurs in low abundance and may easily be overlooked. Coarse clots and sprays of hornblende and actinolite are common on foliation surfaces of the Moretown Formation, and hornblende ( \pm actinolite) and chlorite clots and sprays are common on foliation surfaces of the feldspathic schist of the Cavendish, especially in the hills west of Greenbush.

Staurolite, kyanite, chlorite, actinolite, and garnet all overgrow the dominant $\mathrm{S}_{2}$ schistosity in the Cavendish Formation. Although garnet contains curved inclusion trails, the form of the inclusions commonly mimics the deformed matrix. Garnet, hornblende, chlorite, biotite, or muscovite commonly overgrow the dominant $\mathrm{S}_{2}$ schistosity in the Moretown Formation. In both the Cavendish and Moretown, the $\mathrm{S}_{2}$ schistosity is defined by fine- to medium-grained muscovite, chlorite, biotite, and ilmenite. 
The dominant foliation in the Waits River Formation consists of ultrafine-grained muscovite and biotite and subparallel laminae of carbonaceous dust. Garnet is overgrown on this dominant $S_{2}$ foliation, which includes crenulations produced by microcrenulations. Partial alteration of garnet to chlorite is common throughout the quadrangle, but garnets containing inclusions are completely chloritized near the northwestern corner of the map.

Plagioclase is highly poikiloblastic and occurs in large anhedral grains that include microfolds of the matrix schistosity, especially in the feldspar-rich gneisses of the Cavendish Formation ( $\mathrm{Ycfs}$ ) and Mount Holly Complex. It is clear that metamorphic minerals in most rocks overgrow the $\mathrm{S}_{2}$ schistosity and that textures indicate widespread growth of minerals late in the Acadian structural history.

Previous workers suggest that the main pulse of Acadian metamorphism came after foliation developed and during or after doming. Downie (1982) estimated that peak metamorphic temperatures of $600 \pm 20^{\circ} \mathrm{C}$ occurred at pressures of approximately 6 kilobars (kbars) on the basis of garnet-biotite thermobarometry and plagioclase-garnet-kyanite-quartz geobarometry. Armstrong and Tracy (1991) estimated temperatures of $686 \pm 15^{\circ} \mathrm{C}$ and pressures of 9 to $10 \mathrm{kbar}$ for garnet schist from Star Hill and Gassetts in the Chester quadrangle. These results agree with estimates from phase equilibria (Thompson, Lyttle, and Thompson, 1977) and with studies of inclusions in Thompson, Tracy, and others (1977). Many of the pioneering petrologic studies began at the well-known exposures of the Gassetts Schist Member of the Cavendish Formation at Gassetts (Thompson, 1975; Thompson, Lyttle, and Thompson, 1977; Thompson, Tracy, and others, 1977). Thompson, Cheney, and Robinson (1986) summarized the regional metamorphism, as well as Downie's unpublished data from Star Hill. Sm-Nd and U-Pb dating from the rim of a single garnet from the Gassetts roadcut gave ages of about $380 \mathrm{Ma}$ (Vance and Holland, 1993), although they regarded the $238 \mathrm{U}-206 \mathrm{~Pb}$ model age of $377.8 \pm 3.4 \mathrm{Ma}$ as a better estimate for the growth of the garnet rim. By comparing the petrogenetic grid and thermochemical calculations with observed compositions of inclusions, they concluded that the garnets may have grown during decompression from 9.7 to $7.2 \mathrm{kbar}$ at temperatures of $635^{\circ} \mathrm{C}$ at the lower pressures. These pressures are significantly higher than earlier ones using mineral geobarometers and geothermometers.

Peak metamorphic conditions appear to have happened after the development of the regional $\mathrm{S}_{2}$ foliation and retrogressive metamorphic reactions in the basement rocks. Muscovite and epidote define the metamorphic fabric especially well in the plagioclase-rich gneisses of the Mount Holly Complex. However, later growth of poikiloblastic plagioclase and, locally, of microcline is widespread. Calc-silicate rocks and hornblende-garnet amphibolites of the Mount Holly Complex are highly foliated and contain abundant younger actinolite, chlorite, biotite, and clinozoisite aligned with the $\mathrm{S}_{2}$ foliation surface. Diopside marble and rocks containing diopside knots have been extensively retrograded to actinolite, talc, and clinozoisite assemblages, which define the strong $\mathrm{S}_{2}$ fabric.

The Acadian metamorphic peak has been estimated by the ${ }^{39} \mathrm{Ar}-40 \mathrm{Ar}$ hornblende plateau cooling ages from core gneisses in the Chester dome at $379 \pm 2$ and $374 \pm 2 \mathrm{Ma}$ (Spear and Harrison, 1989). Their samples (Ar-Ch-2 and $\mathrm{Ar}-\mathrm{Ch}-3$ ) came from $1 \mathrm{~km}$ south of the well-known exposures of the Gassetts Schist Member at Gassetts discussed by Thompson, Lyttle, and Thompson (1977) and Thompson, Tracy, and others (1977). These age dates agree with regional data of Sutter and others (1985) and Laird and others (1984) from the Acadian zone of southern Vermont.
Garnet, biotite, kyanite, and plagioclase formed as static overgrowths on the regional $\mathrm{S}_{2}$ foliation or as syntectonic growths during development of the northeast- and northwest-trending crenulation cleavages. From the mineralogy, the $\mathrm{S}_{2}$ deformation is Acadian or older and the compressive stages of dome uplift and folding are Acadian; both occurred before the closure of amphibole at about $550^{\circ} \mathrm{C}$ to the diffusion of argon at about $379 \mathrm{Ma}$. Crosscutting dikes of two-mica granodiorite are widespread throughout the core of the Chester dome. These dikes must be later than peak metamorphism because they cut schistosities that contain syntectonic and post-tectonic garnet. The age of these dikes is unknown, but a biotite granite dike at Black Mountain in the core of the Guilford dome has been dated at $373 \pm 4$ Ma from U-Pb zircon studies by J.N. Aleinikoff (written commun., 1992). Assuming a comparable age for granitic dikes in the Cavendish area, the formation of the main crenulation cleavage in the core of the dome and on the western limb is older than $374 \mathrm{Ma}$. Near the eastern margin of the dome, northeast-trending $\mathrm{F}_{4}$ folds and northsouth $F_{5}$ folds in the granites suggest that structures may have become younger and more intense to the east. Similar relations have been determined at the southern end of the Athens dome by Armstrong (1992) and Ratcliffe and others (1992).

The dominant effects of metamorphism and deformation in the Cavendish quadrangle appear to be the result of the Acadian orogeny. These intense events occurred very late in the structural history, possibly during or later than formation of the dome itself. The form of the dome is clearly the result of cross folding (shortening) in at least two directions after the thrust faulting and regional intense foliation, which were also probably Acadian. Clear evidence for Taconian structures is lacking, but almost certainly they were present in the Cambrian and Ordovician rocks of the mantle before being masked by Acadian features.

\section{REFERENCES CITED}

Aleinikoff, J.N., and Karabinos, P.A., 1990, Zircon U-Pb data for the Moretown and Barnard volcanic members of the Missisquoi Formation and a dike cutting the Standing Pond Volcanics, southeastern Vermont, in Slack, J.F., ed., Summary results of the Glens Falls CUSMAP project, New York, Vermont, and New Hampshire: U.S. Geological Survey Bulletin 1887, p. D1-D10.

Armstrong, T.R., 1992, Progressive evolution of Acadian dynamothermal events in southern Vermont: Geological Society of America Abstracts with Programs, v. 24, no. 3, p. 4.

1994, Bedrock geology of the Moretown Formation, North River Igneous Suite and associated metasedimentary/metavolcanic rocks of the Connecticut Valley Belt, Brattleboro and Newfane quadrangles, Windham County, Vermont: U.S. Geological Survey Open-File Report 94-247, 26 p., scale 1:24,000.

Armstrong, T.R., and Tracy, R.J., 1991, Tectonometamorphic evolution of Acadian domes in southern Vermont: Geological Society of America Abstracts with Programs, v. 23, no. 1, p. 3.

Balk, Robert, and Krieger, Philip, 1936, Devitrified felsite dikes from Ascutney Mountain, Vermont: American Mineralogist, $v$. 21 , no. 8, p. 516-522.

Chang, P.H., Ern, E.H., Jr., and Thompson, J.B., Jr., 1965, Bedrock geology of the Woodstock quadrangle, Vermont: Vermont Geological Survey Bulletin 29, 65 p., scale $1: 62,500$. 
Chapman, R.W., and Chapman, C.A., 1940, Cauldron subsidence at Ascutney Mountain, Vermont: Geological Society of America Bulletin, v. 51, no. 2, p. 191-211.

Currier, L.W., and Jahns, R.H., 1941, Ordovician stratigraphy of central Vermont: Geological Society of America Bulletin, v. 52, no. 9, p. 1487-1512.

Daly, R.A., 1903, The geology of Ascutney Mountain, Vermont: U.S. Geological Survey Bulletin 209, 122 p.

Daniels, D.L., 1990, Magnetic and gravity expression of Cretaceous alkalic plutonic complexes at Cuttingsville and Mount Ascutney, Vermont, in Slack, J.F., ed., Summary results of the Glens Falls CUSMAP project, New York, Vermont, and New Hampshire: U.S. Geological Survey Bulletin 1887, p. C1-C8.

Doll, C.G., Cady, W.M., Thompson, J.B., Jr., and Billings, M.P., comps. and eds., 1961, Centennial geologic map of Vermont: Montpelier, Vermont Geological Survey, scale 1:250,000.

Downie, E.A., 1982, Structure and metamorphism in the Cavendish area, north end of the Chester dome, southeastern Vermont: Cambridge, Mass., Harvard University, Ph.D. thesis, 349 p., scale 1:12,000.

Faul, Henry, Stern, T.W., Thomas, H.H., and Elmore, P.L.D., 1963. Ages of intrusion and metamorphism in the northern Appalachians: American Journal of Science, v. 261, no. 1, p. 1-19.

Foland, K.A., Henderson, C.M.B., and Gleason, James, 1985, Petrogenesis of the magmatic complex at Mount Ascutney, Vermont, USA; Assimilation of crust by mafic magmas based on $\mathrm{Sr}$ and $\mathrm{O}$ isotopic and major element relationships: Contributions to Mineralogy and Petrology, v. 90, no. 4, p. 331-345.

Hames, W.E., and Cheney, J.T., 1997, On the loss of 40Ar from muscovite during polymetamorphism: Geochimica et Cosmochimica Acta, v. 61, no. 18, p. 3863-3872.

Harrison, T.M., Spear, F.S., and Heizler, M.T., 1989, Geochronologic studies in central New England; II, PostAcadian hinged and differential uplift: Geology, v. 17, no. 2, p. 185-189.

Hatch, N.L, Jr., 1991, Revisions to the stratigraphy of the Connecticut Valley trough, eastern Vermont, in Stratigraphic notes 1989-90: U.S. Geological Survey Bulletin 1935, p. 5-7.

Hubacher, F.A., and Foland, K.A., 1991, ${ }^{40 \mathrm{Ar} / 39} \mathrm{Ar}$ ages for Cretaceous intrusions of the White Mountain magma series, northern New England, and their tectonic implications: Geological Society of America Abstracts with Programs, v. 23, no. 1, p. 47

Hueber, F.M., Bothner, W.A., Hatch, N.L., Jr., Finney, S.C., and Aleinikoff, J.N., 1990, Devonian plants from southern Quebec and northern New Hampshire and the age of the Connecticut Valley trough: American Journal of Science, v. 290, no. 4, p. 360-395.

Karabinos, Paul, and Aleinikoff, J.N., 1990, Evidence for major Middle Proterozoic, post-Grenvillian igneous event in western New England: American Journal of Science, v. 290, no. 8, p. 959-974.

Karabinos, Paul, and Thompson, J.B., Jr., 1997, Basement-cover relationships in southern Vermont, in Grover, T.W., Margo, H.N., and Hasenohr, E.J., eds., Guidebook to field trips in Vermont and adjacent New Hampshire and New York: New England Intercollegiate Geological Conference, 89th Annual Meeting, Killington-Pico Region, Vt., Sept. 19-21, 1997, p. B3-1-20.
Karabinos, Paul, Samson, S.D., Hepburn, J.C., and Stoll, H.M., 1998, Taconian orogeny in New England Appalachians; Collision between Laurentia and the Shelburne Falls arc: Geology, v. 26, no. 3, p. 215-218.

Karabinos, Paul, Aleinikoff, J.N., and Fanning, C.M., 1999, Distinguishing Grenvillian basement from pre-Taconian cover rocks in the northern Appalachians: American Journal of Science, v. 299, p. 502-515.

Laird, Jo, Lanphere, M.A., and Albee, A.L., 1984, Distribution of Ordovician and Devonian metamorphism in mafic and pelitic schists from northern Vermont, in Misra, K.C., and others, eds., Mafic and ultramafic rocks of the Appalachian orogen: American Journal of Science, v. 284, no. 4-5, p. 376-413.

Nisbet, B.W., 1976, Structural studies in the northern Chester dome of east-central Vermont: Albany, State University of New York, Ph.D. thesis, 265 p., scale 1:2,400.

Ratcliffe, N.M., 1991, Revisions of the nomenclature of some Middle Proterozoic granitic rocks in the northern Berkshire massif, Massachusetts, and the southern Green Mountains, Vermont and Massachusetts, in Stratigraphic notes 1989-90: U.S. Geological Survey Bulletin 1935, p. 9-26.

1992, Preliminary bedrock geologic map of the Mount Holly quadrangle and portions of the Ludlow quadrangle, Rutland and Windsor Counties, Vermont: U.S. Geological Survey Open-File Report OF-92-282-A, two sheets, scale $1: 24,000$.

1993, Bedrock geologic map of the Mount Snow and Readsboro quadrangles, Bennington and Windham Counties, Vermont: U.S. Geological Survey Miscellaneous Investigations Series Map I-2307, scale 1:24,000.

1994, The Wilcox Formation of Vermont assigned to the Mount Holly Complex, in Stratigraphic notes 1992: U.S. Geological Survey Bulletin 2060, p. 11-18.

1997, Bedrock geologic map of the Jamaica and part of the Townshend quadrangles, Windham and Bennington Counties, Vermont: U.S. Geological Survey Miscellaneous Investigations Series Map 1-2453, scale 1:24,000.

Ratcliffe, N.M., and Burton, W.C., 1996, Digital bedrock geologic map of the Weston quadrangle, Vermont: U.S. Geological Survey Open-File Report 96-526-B, scale 1:24,000.

Ratcliffe, N.M., Aleinikoff, J.N., Burton, W.C., and Karabinos, P.A., 1991, Trondhjemitic 1.35-1.3 Ga gneisses of the Mount Holly Complex of Vermont; and evidence for an Elzevirian event in the Grenville province of the U.S. Appalachians: Canadian Journal of Earth Sciences, v. 28, no. 1, p. 77-93.

Ratcliffe, N.M., Armstrong, T.R., and Tracy, R.J., 1992, Tectoniccover basement relations and metamorphic conditions of formation of the Sadawga, Rayponda, and Athens domes, southern Vermont, in Robinson, Peter, and Brady, J.B., eds., Guidebook for field trips in the Connecticut Valley region of Massachusetts and adjacent states: New England Intercollegiate Geological Conference, 84th Annual Meeting, Amherst, Mass., Oct. 9-11, 1992, v. 2, p. 257-290.

Ratcliffe, N.M., Armstrong, T.R., and Aleinikoff, J.N., 1997, Stratigraphy, geochronology, and tectonic evolution of the basement and cover rocks of the Chester and Athens domes, in Grover, T.W., Margo, H.N., and Hasenohr, E.J., eds., Guidebook to field trips in Vermont and adjacent New Hampshire and New York: New England Intercollegiate Geological Conference, 89th Annual Meeting, Killington-Pico Region, Vt., Sept. 19-21, 1997, p. B6-1-B6-55.

Ratcliffe, N.M., Walsh, G.J., and Aleinikoff, J.N., 1997, Basement, metasedimentary and tectonic cover covers the Green 
Mountain massif and western flank of the Chester dome, in Grover, J.W., Margo, H.N., and Hasenohr, E.J., eds., Guidebook to field trips in Vermont and adjacent New Hampshire and New York: New England Intercollegiate Geological Conference, 89th Annual Meeting, Killington-Pico Region, Vt., Sept. 19-21, 1997, p. C6-1-C6-54.

Richardson, C.H., 1929, The geology and petrography of Reading, Cavendish, Baltimore, and Chester, Vermont: Vermont Geological Survey, Report of the State Geologist for 1928, 16th annual report, p. 208-248.

Rosenfeld, J.L., 1954, Geology of the southern part of the Chester dome, Vermont: Cambridge, Mass., Harvard University, unpub. Ph.D. thesis, $303 \mathrm{p}$.

1968, Garnet rotations due to the major Paleozoic deformations in southeast Vermont, in Zen, E-an, White, W.S., Hadley, J.B., and Thompson, J.B., Jr., eds., Studies of Appalachian geology, northern and maritime: New York, Interscience Publishers, chap. 14, p. 185-202.

Schneiderman, J.S., 1989, The Ascutney Mountain breccia; Field and petrologic evidence for an overlapping relationship between Vermont sequence and New Hampshire sequence rocks: American Journal of Science, v. 289, no. 6, p. 771-811.

Sheppard, S.M.F., and Schwarcz, H.P., 1970, Fractionation of carbon and oxygen isotopes and magnesium between coexisting metamorphic calcite and dolomite: Contributions to Mineralogy and Petrology, v. 26, p. 161-198.

Spear, F.S., and Harrison, T.M., 1989, Geochronologic studies in central New England; I, Evidence for pre-Acadian metamorphism in eastern Vermont: Geology, v. 17, no. 2, p. 181-184.

Stanley, R.S., and Ratcliffe, N.M., 1985, Tectonic synthesis of the Taconic orogeny in western New England: Geological Society of America Bulletin, v. 96, no. 10, p. 1227-1250.

Sutter, J.F., Ratcliffe, N.M., and Mukasa, S.B., $1985,{ }^{40} \mathrm{Ar} / 39 \mathrm{Ar}$ and K-Ar data bearing on the metamorphic and tectonic history of western New England: Geological Society of America Bulletin 96, no. 1, p. 123-136.

Thompson, A.B., 1975, Mineral reactions in a calc-mica schist from Gassetts, Vermont, USA: Contributions to Mineralogy and Petrology, v. 53, no. 2, p. 105-127.

Thompson, A.B., Lyttle, P.T., and Thompson, J.B., Jr., 1977, Mineral reactions and A-Na-K and A-F-M facies types in the Gassetts Schist, Vermont: American Journal of Science, v. 277, no. 9, p. 11241151.

Thompson, A.B., Tracy, R.J., Lyttle, P.T., and Thompson, J.B., Jr., 1977, Prograde reaction histories deduced from composi- tional zonation and mineral inclusions in garnet from the Gassetts Schist, Vermont: American Journal of Science, v. 277, no. 9, p. 1152-1167.

Thompson, J.B., Jr., 1950, A gneiss dome in southeastern Vermont: Cambridge, Massachusetts Institute of Technology, Ph.D. thesis, 149 p., scale 1:62,500.

Thompson, J.B., Jr., Cheney, J.T., and Robinson, Peter, 1986, Metamorphism on the east flank of the Green Mountain massif and Chester dome, in Robinson, Peter, and Elbert, D.C., eds., Field trip guidebook; Regional metamorphism and metamorphic phase relations in northwestern and central New England, Trip B-5: 14th General Meeting International Mineralogical Association at Stanford University; Amherst, University of Massachusetts, Contributions of the Geology Department, no. 59, p. 94-119.

Thompson, J.B., Jr., Rosenfeld, J.L., and Downie, E.A., 1986, Basement-cover relations in the Chester and Athens domes and adjacent terranes, Vermont: Geological Society of America Abstracts with Programs, v. 18, no. 1, p. 71.

Thompson, J.B., Jr., McLelland, J.M., and Rankin, D.W., 1990, Simplified geologic map of the Glens Falls $1^{\circ} \times 2^{\circ}$ quadrangle, New York, Vermont, and New Hampshire: U.S. Geological Survey Miscellaneous Field Studies Map MF-2073, scale 1:250,000.

Thompson, J.B., Jr., Rosenfeld, J.L., and Chamberlain, C.P., 1993, Sequence and correlation of tectonic and metamorphic events in southeastern Vermont, Trip B, in Cheney, J.T., and Hepburn, J.C., eds., Field trip guidebook for the northeastern United States; 1993 Boston Geological Society of America Meeting: Boston, Mass., 1993 Geological Society of America Annual Meeting, p. B-1-B-26.

Vance, Derek, and Holland, Tim, 1993, A detailed isotopic and petrological study of a single garnet from the Gassetts Schist, Vermont: Contributions to Mineralogy and Petrology, v. 114, no. 1, p. $108-118$.

Walsh, G.J., and Ratcliffe, N.M., 1993, Lithostratigraphy and internal structure of the Ottauquechee Formation, southern Vermont: Geological Society of America Abstracts with Programs, v. 25, no. 2, p. 87.

1994, Preliminary bedrock geologic map of the Plymouth quadrangle and eastern part of the Killington Peak quadrangle, Vermont: U.S. Geological Survey Open-File Report OF-94-225, scale 1:24,000.

Zimmerman, R.A., Reimer, G.M., Foland, K.A., and Faul, Henry, 1975, Cretaceous fission track dates of apatites from northern New England: Earth and Planetary Science Letters, v. 28, no. 2, p. $181-188$. 
